\title{
The Trade Secrecy Standard for Patent Prior Art
}

Sharon Sandeen

Mitchell Hamline School of Law, sharon.sandeen@mitchellhamline.edu

Camilla A. Hrdy

Follow this and additional works at: https://open.mitchellhamline.edu/facsch

Part of the Intellectual Property Law Commons

Publication Information

70 American University Law Review 1269 (2021)

\section{Repository Citation}

Sandeen, Sharon and Hrdy, Camilla A., "The Trade Secrecy Standard for Patent Prior Art" (2021). Faculty Scholarship. 499.

https://open.mitchellhamline.edu/facsch/499

This Article is brought to you for free and open access by Mitchell Hamline Open Access. It has been accepted for inclusion in Faculty Scholarship by an authorized administrator of Mitchell Hamline Open Access. For more information, please contact sean.felhofer@mitchellhamline.edu.

\section{$\mathrm{MH}$} MITCHELL | HAMLINE OPEN ACCESS selod for the mitchellhamline.edu 


\title{
The Trade Secrecy Standard for Patent Prior Art
}

\begin{abstract}
A fundamental criterion of patentability is that an invention must be new as compared to the prior art-the corpus of preexisting knowledge and technology already available to the public. If an invention is in the prior art, or rendered obvious by it, it cannot be patented.

The U.S. Patent Act has traditionally envisioned a categorical approach for deciding what counts as prior art. Under this approach, courts are supposed to decide whether a particular disclosure about the invention (a reference) falls within one of the categories listed in Section 102 of the Patent Act, such as "described in a printed publication," "in public use," or "on sale." Yet the categorical approach lacks a coherent theory of publicness. It is difficult to find guiding principles to explain courts' decisions about what is, or is not, public. For example, a woman wearing a corset invention at home under her clothing was deemed to be an invalidating "public use" that barred future patenting; yet an employee liberally sharing his invention with others at work was not.

We argue that, while courts refer to the statutory categories, they are in reality turning to concepts of publicness that strikingly resemble those of a different legal regime: trade secret law. Indeed, our review of the cases shows that trade secrecy status is dispositive for what counts as prior art in many of the leading cases. At a normative level, we argue that trade secrecy provides a surprisingly effective way to manage the boundary between legally public and legally secret information, and for deciding whether a reference is truly "available to the public" in the ways that matter for patent policy and, indeed, information policy more broadly. Not only does the trade secrecy standard protect peoples' justifiable reliance on information that is already available to them, but it simultaneously makes inventors' paths to patenting more efficient.
\end{abstract}

\section{Keywords}

Patents, Trade secrets, Prior art

Disciplines

Intellectual Property Law 


\title{
ARTICLES
}

\section{THE TRADE SECRECY STANDARD FOR PATENT PRIOR ART}

\author{
CAMILla A. HRDY* \& SHARON K. SANDEEN**
}

\begin{abstract}
A fundamental criterion of patentability is that an invention must be new as compared to the prior art - the corpus of preexisting knowledge and technology already available to the public. If an invention is in the prior art, or rendered obvious by it, it cannot be patented.

The U.S. Patent Act has traditionally envisioned a categorical approach for deciding what counts as prior art. Under this approach, courts are supposed to decide whether a particular disclosure about the invention (a reference) falls within one of the categories listed in Section 102 of the Patent Act, such as "described in a printed publication," "in public use," or "on sale." Yet the categorical approach lacks a coherent theory of publicness. It is difficult to find guiding principles to explain
\end{abstract}

* Research Professor of Law, University of Akron School of Law, Akron, OH. Affiliated Fellow at the Information Society Project, Yale Law School, New Haven, CT.

** Robins Kaplan LLP Distinguished Professor in IP Law and Director of the IP Institute, Mitchell Hamline School of Law, St. Paul, MN. The authors thank Sue Altmeyer, Ann Bartow, Marty Belsky, Dan Brean, Victoria Cundiff, Janet Freilich, Bernadette Genetin, Mike Gentithes, Deb Gerhardt, Tait Graves, Tim Holbrook, Dmitry Karshdedt, Mark Lemley, Dave Levine, Yvette Liebesman, Robert Merges, Doug Moseley, CJ Peters, Jason Ratanen, Michael Risch, Elizabeth Rowe, Rachel Sachs, Chris Seaman, Mike Schuster, Deepa Varadarajan, and participants at the Trade Secrets Roundtable at Washington $\mathcal{E}^{\circ}$ Lee University School of Law, the Works In Progress in Intellectual Property (WIPIP) Conference at Santa Clara Law, the Faculty Scholarship Workshop at the University of Akron School of Law, the IP Scholars Summer Roundtable on June 1, 2020, the 2020 Junior IP Scholars (JIPSA) draft exchange, and the trade secrecy panel at Stanford Law's 2020 Intellectual Property Scholars Conference (IPSC) on August 5, 2020. Many thanks to the outstanding editors at American University Law Review for all of their work in editing this Article. 
courts' decisions about what is, or is not, public. For example, a woman wearing a corset invention at home under her clothing was deemed to be an invalidating "public use" that barred future patenting; yet an employee liberally sharing his invention with others at work was not.

We argue that, while courts refer to the statutory categories, they are in reality turning to concepts of publicness that strikingly resemble those of a different legal regime: trade secret law. Indeed, our review of the cases shows that trade secrecy status is dispositive for what counts as prior art in many of the leading cases. At a normative level, we argue that trade secrecy provides a surprisingly effective way to manage the boundary between legally public and legally secret information, and for deciding whether a reference is truly "available to the public" in the ways that matter for patent policy and, indeed, information policy more broadly. Not only does the trade secrecy standard protect peoples' justifiable reliance on information that is already available to them, but it simultaneously makes inventors' paths to patenting more efficient.

\section{TABLE OF CONTENTS}

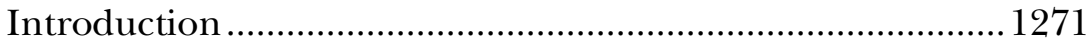

I. Section 102 Prior Art and Its Discontents ......................... 1277

A. 1952 Patent Act Prior Art Categories...................... 1278

1. Section 102 (a) novelty categories...................... 1278

2. Section 102(b) statutory bar categories ............1279

B. America Invents Act Prior Art Categories .............. 1280

1. Section 102(a) (1) novelty provision categories

2. Section 102(b) grace period............................. 1281

II. Embracing the "Available to the Public" Benchmark ....... 1282

III. The Trade Secrecy Standard for Prior Art ....................... 1285

A. The Trade Secrecy Standard for Publicness ........... 1286

1. Not generally known or readily ascertainable .. 1287

a. "Generally known”.................................... 1288

b. "Readily ascertainable" .............................. 1288

2. Reasonable measures to maintain secrecy ........ 1289

B. The Trade Secrecy Standard at Work in Prior Art

Case Law............................................................... 1291

1. The "printed publication" case law .................. 1292

2. The "public use" case law.................................. 1298

C. Exceptions to the Trade Secrecy Standard ............ 1307

1. When failing trade secrecy doesn't mean public 
2. When maintaining trade secrecy is still public 1308

a. On sale bar..................................................... 1308

b. Abandonment and the "Metallizing Doctrine" 1311

IV. The Benefits of the Trade Secrecy Standard 1313

A. Supporting the Nonremoval Principle. 1314

1. A functional approach to publicness. 1315

2. A well-developed concept of the relevant public

3. Highlighting the importance of measures to maintain secrecy

B. Streamlining Inventors' Incentives........................1320

1. Inventor prior art ......................................... 1321

2. Third-party prior art....................................... 1323

3. The third-party problem .................................... 1326

C. Fleshing Out "Otherwise Available to the Public"

\section{INTRODUCTION}

A fundamental question in patent law is whether a claimed invention is new as compared to the prior art-the corpus of knowledge and technology that is already available to the public. ${ }^{1}$ If an invention is contained in the prior art, or rendered obvious by it, the invention cannot be patented. ${ }^{2}$ The reason is simple. As a matter of policy, we do not want to grant exclusive rights in inventions that were already invented and available to others, such as competitors and researchers

1. See, e.g., Sean B. Seymore, Rethinking Novelty in Patent Law, 60 Duke L.J. 919, 922 (2011) ("Determining novelty requires a comparison of the invention that the applicant seeks to patent with the 'prior art,' which refers to preexisting knowledge and technology already available to the public."); Timothy Holbrook, Patent Prior Art and Possession, 60 William \& Mary L. Rev. 123, 127 (2018) (defining "prior art" as "the set of information generally known to the hypothetical person having ordinary skill in the art (PHOSITA)").

2. 35 U.S.C. $§ 102$; see also Mark A. Lemley, Point of Novelty, 105 Nw. U. L. Rev. 1253, 1254 (2011); 35 U.S.C. § 103; Graham v. John Deere Co. of Kan. City, 383 U.S. $1,5-6$ (1966). 
in the field who might wish to use them. ${ }^{3}$ Doing so would unjustifiably deprive people of the right to use inventions and information to which they already have access and disrupt the patent bargain by giving the patentee an exclusive right without demanding disclosure of anything new in return. ${ }^{4}$

Under the current regime, determining what counts as prior art requires deciding whether a particular disclosure of information about the invention-called a reference-falls within one of the formal categories of activities listed in Section 102 of the Patent Act. ${ }^{5}$ These statutory categories include disclosures that render the invention "patented"; "described in a printed publication"; "in public use"; "on sale"; or "otherwise available to the public" prior to the critical date. ${ }^{6}$

The cases applying Section 102 are a bit of a mess. ${ }^{7}$ It is often difficult to explain courts' decisions about what counts as sufficiently public to be considered prior art. For example, the Supreme Court found that a woman wearing a corset invention under her clothing fell into the category of a "public use" that rendered an inventor's patent invalid. ${ }^{8}$ So did private laboratory use of a centrifuge by a single research scientist. ${ }^{9}$

3. Bonito Boats, Inc. v. Thunder Craft Boats, Inc., 489 U.S. 141, 156 (1989) ("Both the novelty and the nonobviousness requirements of federal patent law are grounded in the notion that concepts within the public grasp, or those so obvious that they readily could be, are the tools of creation available to all."); see also Seymore, supra note 1 , at 930 .

4. See, e.g., Michael L. Ryan, Novelty in Patent Law, Cornell L. SCH. Hist. TheseS \& Dissertations Collection 3 (1896); see also Comment, Prior Art in the Patent Law, 73 HARV. L. REV. 369, 370 (1959).

5. A reference is information about an invention that is potentially going to be considered prior art. It can refer to a documentary reference (e.g., a journal article) or a nondocumentary reference, such as an activity like a sale or use of the invention. See Sean B. Seymore, The "Printed Publication" Bar After Klopfenstein: Has the Federal Circuit Changed the Way Professors Should Talk About Science?, 40 AKron L. REV. 493, 494 n.6 (2007).

6. As we explain in Part I, infra, the critical date for judging novelty depends on whether the America Invents Act of 2011 (AIA), which switched the United States from a first-to-invent to a first-to-file rule, applies. Compare 35 U.S.C. $\$ 102$ (1952) (outlining novelty requirements for the first-to-invent rule), with 35 U.S.C. $\$ 102$ (2018) (listing novelty requirements for the first-to-file rule).

7. Holbrook, supra note 1, at 127 ("Under the Patent Act of 1952, prior art was defined by 35 U.S.C. $\$ 102$, which was, frankly, a mess. There was no rational structure to its provisions; it was merely a codification of previous judicial decisions arbitrarily listed in no particular order.").

8. Egbert v. Lippmann, 104 U.S. 333, 338 (1881).

9. Baxter Int'l, Inc. v. COBE Labs., Inc., 88 F.3d 1054, 1061 (Fed. Cir. 1996). 
But when an inventor freely shared models of his Rubik's Cube invention with his boss and colleagues at work, the Federal Circuit held this was not "public use" sufficient to invalidate the inventor's later patent. ${ }^{10}$ Meanwhile, a fourteen-slide lecture displayed on a poster for three days, ${ }^{11}$ an article on an obscure website, ${ }^{12}$ and a thesis buried in a library in Germany were all held to constitute "printed publications" under Section 102. ${ }^{13}$ Each were deemed to have entered the prior art and to anticipate patents sought for the same inventions-even though none of these examples meets the ordinary person's understanding of what publication means. ${ }^{14}$

We do not necessarily disagree with the outcomes of these decisions. ${ }^{15}$ Rather, we see them as lacking a consistent theoretical basis. Despite Section 102's categorical approach, it seems clear that the decisionmakers in these cases-in particular the Federal Circuit, which has exclusive jurisdiction over appeals of patent cases $^{16}$-are seeking to determine whether the reference cited in the case resulted in the invention being sufficiently public to matter for patent policy. ${ }^{17}$ On one level, this makes sense. Several of the categories of prior art listed in Section 102 refer explicitly to the idea of publicness; and, as we will show, since 2011, it is even more apparent that courts are supposed to be asking whether the reference is "available to the public."18 However, so far as we can tell, no one has identified a satisfactory theory to explain what it means for a prior art reference to be public.

In this Article, we argue there is, in fact, a consistent theoretical basis underlying courts' prior art decisions. Namely, courts are using concepts of publicness that strikingly resemble those of another legal

10. Moleculon Rsch. Corp. v. CBS, Inc., 793 F.2d 1261, 1265 (Fed. Cir. 1986).

11. In re Klopfenstein, 380 F.3d 1345, 1351-52 (Fed. Cir. 2004).

12. Voter Verified, Inc. v. Election Sys. \& Software, Inc., 698 F.3d 1374, 1380 (Fed. Cir. 2012).

13. In re Hall, 781 F.2d 897, 899-900 (Fed. Cir. 1986).

14. See generally Seymore, supra note 5, at 504-09; see also Stephen Yelderman, Prior Art in the District Court, 95 Notre Dame L. Rev. 837, 862-63 (2019) (“[U]nder the Federal Circuit's Klopfenstein test, printed publication can include things that colloquially would not be understood as 'publications' at all—such as slide shows, poster boards, and handouts displayed or distributed at conferences." (citing Margo A. Bagley, Academic Disclosure and Proprietary Rights: Putting Patents in Their Proper Place, 47 B.C. L. Rev. 217, 221 (2006))).

15. But we will raise some doubts about a few of them in Part III, infra.

16. 28 U.S.C. $\$ 1295$.

17. See infra Part II.

18. See infra Part I. 
regime: trade secret law. Trade secret law creates a cause of action against those who misappropriate information that is kept sufficiently secret. ${ }^{19}$ By necessity, trade secret law developed legal tools to manage the boundary between "secret" and "public" information..$^{20}$ As trade secret scholars who have read thousands of trade secret opinions, it is clear to us that courts in patent law cases use trade secret law concepts, or something very similar to them, to draw the line between public and non-public disclosures of information about inventions, even if courts do not say so directly. ${ }^{21}$

The Article makes two contributions. First, at a descriptive level, we show that courts often draw on trade secrecy concepts of publicness when assessing patent prior art. Indeed, our review of the major prior art cases suggests the trade secrecy status of information is largely dispositive. Just like in a trade secrecy analysis, courts assess: first, whether a reference has rendered information about the invention "generally known" or "readily ascertainable through proper means"; and second, whether the information has been the subject of "reasonable measures" to maintain its secrecy. ${ }^{22}$ If either of these aspects of trade secrecy fail, courts presume the reference is public and in the prior art. But if a reference does qualify as a trade secret, courts tend to consider it non-public and not part of the prior art.

There are important exceptions, which we discuss in detail. But in those cases, we argue, courts are guided by considerations other than publicness, such as the important policy of preventing inventors from commercializing their inventions in secret too long prior to patenting. ${ }^{23}$ The existence of these exceptions, and even of some outlier cases, does not weaken the explanatory power of the general rule. Unless there is some other policy reason separate from information's publicness that

19. 18 U.S.C. $§ 1839(3)$; see also Unif. Trade Secrets Act $§ 1$ (Unif. L. Comm'n 1985). See generally Elizabeth A. Rowe \& Sharon K. Sandeen, Trade Secret Law: Cases AND MATERIALs 1-3, 43-46 (3d ed. 2021).

20. Cf. Michael J. Madison, Open Secrets, in The LaW and Theory of Trade Secrecy: A HANDBOOK OF ConTEMPORARY RESEARCH 222, 223-24 (Rochelle C. Dreyfuss \& Katherine J. Strandburg eds., 2011) (observing that trade secret law supplies a mechanism for "managing boundaries between what is legally secret and what is legally public").

21. As we explain in Part III, infra, courts have recognized the rule indirectly in the course of carving out a major exception. See, e.g., Metallizing Eng'g Co. v. Kenyon Bearing \& Auto Parts Co., 153 F.2d 516, 520 (2d Cir. 1946). Also, the Federal Circuit has recognized the similarity in the standards in its trade secret case law.

22. 18 U.S.C. $\$ 1839$ (3); see also Unif. Trade Secrets Act $\$ 1$.

23. See infra Section III.C. 
mandates treating a reference as prior art, the trade secret status of information is determinative.

The Article's second contribution is normative. We propose that the trade secrecy standard—so long as it is properly applied ${ }^{24}$-has surprising benefits for patent law and policy. There are two main reasons for this. First, using trade secrecy to set the standard for publicness helps enforce what Robert Merges calls the "nonremoval principle" by protecting members of the relevant public from being deprived of what is already freely available to them.$^{25}$ Second, the trade secrecy standard helps make inventors' roads to patenting more efficient. For inventor-produced prior art (where the inventor is in control of the disclosure), the trade secrecy standard employs an efficient "reasonableness" standard for evaluating inventors' confidentiality precautions and clarifies the steps inventors must take to prevent their activities from becoming prior art. Finally, with respect to third-party trade secret uses (especially those that don't place the invention on sale), we believe that application of the trade secrecy standard for prior art is more consistent with the disclosure purposes of patent law. ${ }^{26}$

The upshot is that there could be advantages to making the trade secret standard more consistent and explicit than it currently is. Rather than focusing on fitting a reference into statutory categories that are a matter of historical happenstance, courts (and potentially other decision makers, like patent examiners ${ }^{27}$ ) should focus their efforts on deciding whether an identified disclosure of information qualifies as a trade secret. After doing so, they can then apply applicable exceptions to the general rule that reflect considerations other than publicness. ${ }^{28}$

24. This caveat is essential. An incorrect application of trade secret law that views trade secrecy protection as easier to achieve than it actually is will lead to incorrect outcomes and to less information being deemed part of patent prior art. Importantly, secrecy alone is not enough.

25. See Robert P. Merges, Justifying Intellectual Property 7, 142-43 (2011); see also Robert P. Merges \& John F. Duffy, Patent Law and Policy: Cases and Materials 389 (5th ed. 2011) (discussing the anti-backsliding principle).

26. As we'll discuss, some case law gets this wrong, treating trade secret uses by third parties as prior art. See, e.g., Lockwood v. Am. Airlines, Inc., 107 F.3d 1565, 1570 (Fed. Cir. 1997); see also infra text accompanying notes 313-24.

27. When conducting an evaluation of prior art, patent examiners do not often assess more than patents and information found in printed publications that are available to them. But to the extent issues of publicness arise at the patent office, examiners could draw on a trade secrecy standard as well. We discuss caveats to this in note 79 , infra.

28. See infra Section III.C. 
Our proposal for a trade secrecy standard for prior art is especially timely for two reasons. First, the America Invents Act of 2011 (AIA) made several amendments to Section 102 that make the trade secrecy standard particularly well-suited to applying these amendments. Most obviously, the AIA reveals that the best way to interpret the new language, "otherwise available to the public," is as a new, sui generis category of prior art that encompasses new forms of disclosures that don't qualify as trade secrets. ${ }^{29}$

Second, trade secret and patent law are both legal regimes with the purpose of promoting invention and innovation. ${ }^{30}$ The trade secrecy standard is particularly compelling now that both patent law and trade secret law are federal legal regimes. ${ }^{31}$ Thus, it makes sense that the trade secret status of an informational disclosure under Title 18 of the U.S. Code, where trade secret law is housed, would inform its patent prior art status under Title 35, where patent law is housed. Indeed, even prior to passage of a federal trade secret law, the U.S. Supreme Court indicated in Kewanee Oil Corp. v. Bicron Corp. that trade secret law should be informed by patent policies-in particular, by patent law's "policy that matter once in the public domain must remain in the public domain." 32

This Article provides the framework and justifications for bringing trade secret principles to bear on the patent prior art analysis. ${ }^{33}$ Part I explains the basic patent prior art categories and the relevant changes wrought by the AIA. Part II argues that, at a high level of abstraction, Section 102 mandates that decisionmakers should use public availability as the touchstone for identifying prior art. Part III introduces the trade secrecy standard for patent prior art by showing how the requirements of trade secrecy match up with the categories of patent prior art. It

29. See infra Part IV.D.

30. Kewanee Oil Co. v. Bicron Corp., 416 U.S. 470, 493 (1973). See generally Mark A. Lemley, The Surprising Virtues of Treating Trade Secrets as IP Rights, 61 StAn. L. REv. 311 (2007).

31. Trade secret law in the United States was only state law until recently. On May 11, 2016, Congress passed the Defend Trade Secrets Act (DTSA), transforming trade secret law from a state law regime to a parallel state and federal regime. See 18 U.S.C. $\S \S 1831,1832$; see also infra Part II.

32. Kewanee, 416 U.S. at 484 ("[T] he [patent] policy that matter once in the public domain must remain in the public domain is not incompatible with the existence of trade secret protection. By definition a trade secret has not been placed in the public domain.").

33. See Holbrook, supra note 1, at 193 ("Patent law could likely be better informed by a greater engagement with the law of trade secrecy in this regard."). 
demonstrates that courts have been applying the trade secrecy standard, or something very similar to it, in many of the major prior art cases. It also addresses some of the important exceptions to this general rule. Part IV identifies the normative benefits of adopting a trade secrecy standard for prior art. The Article concludes by summarizing key concepts and by promoting more explicit adoption of the trade secrecy standard.

\section{SECTION 102 PRIOR ART AND ITS DisCONTENTS}

It is not possible to understand the trade secrecy standard for patent prior art without understanding the details of the current categorical approach to prior art-and the developments underway that support turning away from it. So, we start with an explanation.

In the United States, the principle criterion for patentability is that an invention must be new to be patentable. ${ }^{34}$ The novelty requirement, codified in Section 102 of the Patent Act, ensures that an inventor will not be given a twenty-year exclusive right ${ }^{35}$ for an invention to which the public already has access. ${ }^{36}$ The nonobviousness requirement, codified in Section 103, creates an additional hurdle and is commonly justified as reserving patent protection for inventions that would not be invented without the incentive of a patent. ${ }^{37}$

These two requirements work in tandem with one another. Lack of novelty won't bar or invalidate a patent unless every element of the claimed invention is contained in a single prior art reference. ${ }^{38}$ But nonobviousness will, so long as all elements of the claimed invention would be obvious to a "person having ordinary skill in the art" ("PHOSITA") based on the prior art as a whole. ${ }^{39}$

The first step in determining novelty, and eventually nonobviousness, ${ }^{40}$ is to decide which disclosures of the claimed invention, or of information

34. 35 U.S.C. $\$ 102$.

35. $\S 154$ (a) (noting that the current term length of a patent is twenty years).

36. $§ 102$; see also $\S 101$ (providing patent protection to anyone who invents or discovers a "new" invention).

37. § 103; Graham v. John Deere Co., 383 U.S. 1, 5-6 (1966).

38. Seymore, supra note 1, at 931 ("Anticipation requires, first, strict identity between the previously disclosed and the now-claimed subject matter; and, second, an enabling disclosure.").

39. $§ 103$.

40. In general, the same prior art will be used for the Section 103 nonobvious analysis and the Section 102 novelty analysis, except that the obviousness inquiry permits combining different references and, consequently, there are some differences in the universe of relevant prior art. For instance, the "analogous arts" doctrine only 
related to the claimed invention, count as prior art under Section 102. ${ }^{41}$ To constitute Section 102 prior art, the disclosure (a reference) must: (1) be dated prior to the applicable critical date (either invention or filing date, depending on when the patent was filed, as discussed below); (2) enable every element of the claimed invention so that others can practice $\mathrm{it}^{42}$; and, most importantly for present purposes, (3) be sufficiently public to fall within one of Section 102's delineated categories as defined by prior art jurisprudence. ${ }^{43}$

Under the first Patent Act of 1790, there was just one category of patent prior art: the invention had to be "known or used" prior to the invention date. ${ }^{44}$ Over the years, the categories of prior art ballooned, but unfortunately not in a coherent way. ${ }^{45}$ Making things more complicated, the patent system currently has two distinct sets of categories of prior art, depending on when the patent was filed.

\section{A. 1952 Patent Act Prior Art Categories}

If a patent was filed before March 16, 2013, the old "pre-AIA" categories of prior art delineated in the Patent Act of 1952 (the "1952 Act") apply. The types of references that count as prior art are contained in Section 102(a), the novelty provision, and in Section 102(b), the statutory bar provision.

\section{Section 102(a) novelty categories}

Section 102(a) states that "[a] person shall be entitled to a patent unless ... the invention was known or used by others in this country, or patented or described in a printed publication in this or a foreign country, before the invention thereof by the applicant for patent." ${ }^{46}$

allows combining prior art within the same field of endeavor as the invention, or prior art related to the problem the invention seeks to solve. In re Bigio, 381 F.3d 1320, 1325 (Fed. Cir. 2004).

41. Holbrook, supra note 1, at 134 ("Defining what constitutes 'prior art' is a critical aspect of the gatekeeping function performed by the USPTO and the federal courts, ensuring that patents are awarded for only merit-worthy inventions.").

42. This means satisfying both "strict identity" and "anticipatory enablement." Seymore, supra note 1, at 923, 933. The reference must, to some degree, enable every element of the claimed subject matter such that a PHOSITA could make and use it. Id. at 923 .

43. See generally Merges \& Duffy, supra note 25, at 403-32, 529-52; Craig NARD, The LAW OF PATENTS 280-81 (3d ed. 2014).

44. See Patent Act of 1790, ch.7, § 1, 1 Stat. 109, 109-10 (repealed 1793).

45. See Holbrook, supra note 1, at 127.

46. 35 U.S.C. $\$ 102(a)$ (1952). 
Pursuant to this text, Section 102(a) references fall into three categories: the invention was "known or used by others" in the United States, or "patented" or "described in a printed publication" anywhere, before the invention date. ${ }^{47}$

Section 102(a) prior art can only include references that come out prior to the inventor's invention date. ${ }^{48}$ This is because the first-toinvent rule focuses on who was first to invent, not just about whether the invention was already previously publicly available. ${ }^{49}$ Patentees can thus "swear behind" Section 102(a) prior art that comes out before they file the patent by proving an earlier invention date..$^{50}$

\section{Section 102(b) statutory bar categories}

Section 102(b), called the statutory bar, provides that, even if the invention is otherwise novel as of the invention date, a patent will still not be allowed if "the invention was patented or described in a printed publication in this or a foreign country or in public use or on sale in this country, more than one year prior to the date of the application for patent in the United States." ${ }^{\text {1 }}$

Pursuant to this text, Section 102(b) statutory bar prior art includes four categories of activity: the invention was "patented" anywhere; "described in a printed publication" anywhere; "in public use" in the United States; or "on sale" in the United States more than one year prior to the filing date. ${ }^{52}$

Unlike Section 102(a) novelty prior art, Section 102(b) statutory prior art can also include references dated after the invention date, so long as they fall more than one year prior to the patent filing date..$^{53}$ This is because the statutory bar's primary purpose was to ensure that an inventor couldn't get a patent for an invention by swearing behind her invention date in situations where intervening events-including the inventor's own activities, as well as third parties'-made the invention

47. Id.

48. Id.; see also $\$ 103$ (obviousness judged at time of invention).

49. David S. Abrams \& R. Polk Wagner, Poisoning the Next Apple? The America Invents Act and Individual Inventors, 65 STAN. L. REv. 517, 523-26 (2013).

50. Id. at 529-30.

51. 35 U.S.C. $\$ 102$ (b) (1952).

52. Id. Note that earlier versions of this bar set a two-year deadline, which is why Egbert v. Lippmann, for instance, used a two-year measure. 104 U.S. 333, 338 (1881).

53. $§ 102(b)$. 
available to the public by the time of patenting. ${ }^{54}$ The effect of the bar under the 1952 Act is that inventors have a one-year grace period, after the statutory bar is triggered, in which to file a patent application.

The graphic below provides a timeline for helping the reader conceptualize pre-AIA prior art categories.

\section{Pre-AIA Prior Art}

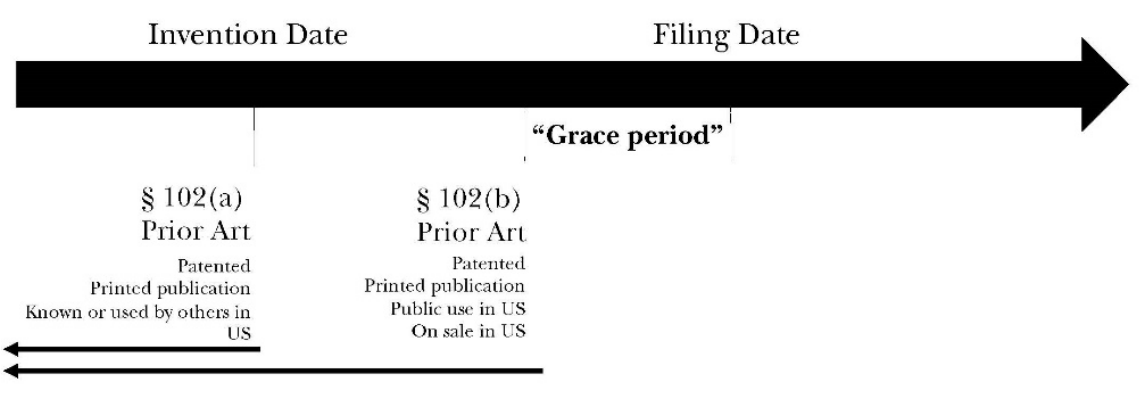

\section{B. America Invents Act Prior Art Categories}

The AIA categories apply to patent applications filed after March 16, 2013. Significantly, the AIA switched the critical date for judging novelty and nonobviousness to the date the subject patent application was filed ${ }^{55}$ and eliminated the first-to-invent rule. ${ }^{56}$ Under the AIA, any prior art, including inventor or third-party prior art, that existed before the filing date will count, so long as it falls into the AIA Section 102(a) (1) categories.

\section{Section 102(a)(1) novelty provision categories}

Even though it covers a longer temporal range, the AIA Section 102(a) (1) categories largely track the pre-AIA categories. Indeed, the AIA simply merged the categories in the old novelty provision of Section 102(a) and the old statutory bar of Section 102(b) into a single provision-the all-

54. The Supreme Court first identified this problem in 1829, which led Congress to codify a precursor to the 1952 Act statutory bar. Pennock v. Dialogue, 27 U.S. 1, 1920 (1829), discussed in Part III, infra.

55. 35 U.S.C. $\$ 102$ (a) (1); see $\$ 103$ (obviousness now judged as of filing date).

56. The exceptions are: (1) derivation, which is where another person claims she invented what an inventor claims in a patent derivation proceeding; and (2) what can be thought of as a "saving disclosure" under Section 102(b)'s new grace period. $\S \S 102(\mathrm{~b}), 135(\mathrm{a})(1)$; see also Merges, supra note 25, at 5. 
encompassing AIA Section 102(a)(1). It states that: "[a] person shall be entitled to a patent unless ... the claimed invention was patented, described in a printed publication, or in public use, on sale, or otherwise available to the public before the effective filing date of the claimed invention. ${ }^{57}$ Thus, there are now five categories of prior art listed.

Note that Section 102(a) (1) has no territorial restriction anymoreeach of the forms of prior art can emerge anywhere in the world. ${ }^{58}$ Note too that the AIA removed the old Section 102(a) "known or used by others" in the United States category, but added a new catchall category, "otherwise available to the public," which arguably captures, among other things, the old "known or used" concept.

\section{Section 102(b) grace period}

The AIA's change to a first-to-file system eliminates the need for a separate statutory bar to capture disclosures between the invention date and the filing date because patentees can no longer swear behind prior art by proving an earlier invention date. ${ }^{59}$ Nonetheless, AIA Section 102(b) replicates some of the effects of the old $\S 102$ (b) grace period by excluding at least some inventor-generated prior art that is generated within a year prior to filing. For example, a disclosure "made by the inventor or joint inventor or by another who obtained the subject matter disclosed directly or indirectly from the inventor or a joint inventor" is exempted if it is generated within a year before the filing date. ${ }^{60}$

The graphic below provides a timeline for conceptualizing the AIA categories of prior art.

57. $§ 102(a)(1)$. Section 102(a)(2) covers prior issued patents and prior filed patent applications, to ensure the true first filer gets the patent. $\$ 102$ (a) (2).

58. See Craig Nard, The Law of Patents 279-80 (3d ed. 2014) (discussing the AIA's elimination of territorial restrictions on prior art); see also Timothy R. Holbrook, What Counts as Extraterritorial in Patent Law?, 25 B.U. J. SCI. \& TECH. L. 291, 321-22 (2019) (discussing choice of law issues created by expanding the on-sale bar to other countries).

59. Robert P. Merges, Priority and Novelty Under the AIA, 27 Berkeley TeCH. L.J. 1023, 1038 (2012).

60. $\S 102(\mathrm{~b})(1)$. 


\section{Post-AIA Prior Art}

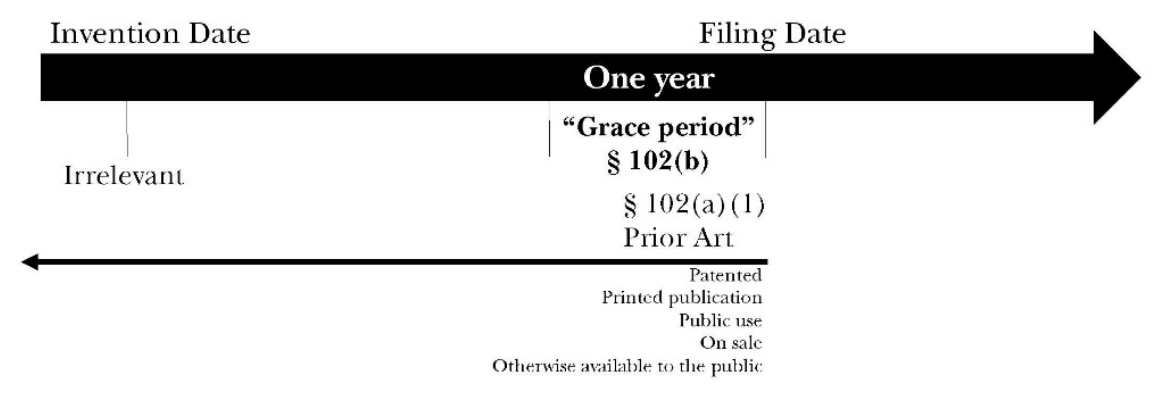

\section{EMBRACING THE “AVAILABLE TO THE PUbliC" BENCHMARK}

The categorical approach to prior art depicted above forces courts to fit a given piece of prior art into somewhat arbitrary statutory categories. But disclosures of information can take innumerable forms, ranging from dissemination in books to use of an invention in a facility without sufficient security. ${ }^{61}$ What matters at the end of the day is not what form the reference takes-whether it qualifies specifically as a "printed publication," a "public use," or an "on sale" event. Rather, the critical question is whether the disclosure is sufficiently public to matter for patent policy.

The primary policy consideration underlying Section 102 and the novelty rules is protecting public access to information that is already publicly available. ${ }^{62}$ This is a species of what Robert Merges calls the nonremoval principle, which holds that no patents shall be granted "for anything that was previously available in any publicly accessible form." 63

It is crucial to note that nonremoval has not historically been the only concern underlying what counts as prior art. Other policies may come into play that have nothing to do with whether the invention is

61. See cases discussed in Part 0, infra.

62. See, e.g., Helsinn Healthcare S.A. v. Teva Pharms. USA, Inc., 139 S. Ct. 628, 632 (2019) ("One such condition is the [Section 102] on-sale bar, which reflects Congress' 'reluctance to allow an inventor to remove existing knowledge from public use' by obtaining a patent covering that knowledge." (quoting Pfaff v. Wells Elecs., Inc., 525 U.S. 55, 64 (1998))).

63. See Merges, supra note 25, at 6, 142-43. 
publicly available. These include respect for first inventorship, ${ }^{64}$ ensuring prompt filing of patents, ${ }^{65}$ allowing inventors to conduct necessary experiments prior to filing patents, ${ }^{66}$ and enforcing the rule that inventors are not supposed to commercialize their inventions for too long prior to patenting. ${ }^{67}$ These considerations give rise to exceptions, where publicness is not necessarily dispositive for identifying prior art. ${ }^{68}$

But nonetheless, courts and commentators have often stated that the main purpose of Section 102 is to ensure the invention is not already "available to the public." ${ }^{69}$ In other words, the question is not whether a reference fit within a particular categorical form; it is whether the reference resulted in the invention being sufficiently public to matter for patent policy. ${ }^{70}$

Post-AIA, public availability is even more central to how Section 102 works. The main reason is that first-to-file is the basis for priority rather than first-to-invent. This means patentees can't swear behind prior art once it becomes public by proving an earlier invention date; public

64. The question of who came first was very important pre-AIA, see $\S 102(\mathrm{~g})$ (2006) (pre-AIA), but is obviously less so post-AIA. See, e.g., Abrams \& Wagner, supra note 49 , at 519-20.

65. See, e.g., Netscape Commc'ns Corp. v. Konrad, 295 F.3d 1315, 1320 (Fed. Cir. 2002) ("The [Section 102(b)] public use bar serves the policies of the patentsystem, for it encourages prompt filing of patent applications after inventions have been completed ...." (quoting Allied Colloids Inc. v. Am. Cyanamid Co., 64 F.3d 1570, 1574 (1995))).

66. Inventors are permitted to engage in "experimental use" of inventions before patenting, even if that experimental use necessarily makes the invention wholly public. See Elizabeth v. Pavement Co., 97 U.S. 126, 129 (1877).

67. Prior to the Supreme Court's decision in Pfaff, the Federal Circuit used to balance four different policy considerations, only one of which was the removal of something from the public. See Petrolite Corp. v. Baker Hughes Inc., 96 F.3d 1423, 1425 (Fed. Cir. 1996).

68. See infra Part III.C.

69. See Merges, supra note 25, at 6, 142-43.

70. See Pfaff v. Wells Elecs., Inc., 525 U.S. 55, 64 (1998); In re Wyer, 655 F.2d 221, 226 (C.C.P.A. 1981); UMC Elecs. Co. v. United States, 816 F.2d 647, 652 (Fed. Cir. 1987), overruled on other grounds by Pfaff v. Wells Elecs., Inc., 525 U.S. 55 (1998), as recognized in Scaltech, Inc. v. Retec/Tetra, LLC, 269 F.3d 1321, 1328 (Fed. Cir. 2011); In re Carlson, 983 F.2d 1032, 1037 (Fed. Cir. 1992); Woodland Tr. v. Flowertree Nursery, Inc., 148 F.3d 1368, 1370 (Fed. Cir. 1998); see also Holbrook, supra note 1, at 147 ("The lodestar [in prior art determinations] has been public accessibility, such that the public must have been able to find the art generally, even if finding it would be difficult."); Seymore, supra note 5, at 504 (“'[P] rinted publication' has been interpreted to mean ... sufficiently accessible to the public interested in the art; dissemination and public accessibility are the keys to the legal determination whether a prior art reference was 'published.”'). 
availability wins the day. ${ }^{71}$ Congress explicitly recognizes this feature of the AIA by newly providing that any disclosure of information that makes the invention "otherwise available to the public" can count as prior art, regardless of the specific form it takes. ${ }^{72}$ While the precise meaning of Section 102's new phrase, "available to the public," has been the subject of considerable debate ${ }^{73}$ few would argue with the proposition that public availability matters for deciding whether something is in the prior art, or with the patent system's underlying policy of nonremoval: once it's public, "thou shalt not take it away."

The upshot, for our purposes, is that the categorical approach to prior art may be waning. Rather than attempting to fit square pegs into round holes, the ultimate question for the decisionmaker should be whether a putative prior art reference was sufficiently public. Indeed, even the notoriously formulaic U.S. Patent and Trademark Office has made statements to this effect, instructing patent examiners to "focus on whether the disclosure was 'available to the public,' rather than on the means by which the claimed invention became available to the public." 75

This evolving approach to prior art creates an opportunity for courts and other decisionmakers ${ }^{76}$ to turn to trade secret law as the baseline for what public availability means.

71. See Merges, supra note 25 , at 5.

72. 35 U.S.C. $\$ 102$.

73. See infra Section IV.C.

74. There is plentiful support for this proposition from a variety of actors in the patent system. The Federal Circuit, for example, has stated that it is a:

[B] asic principle ... that no patent should be granted which withdraws from the public domain technology already available to the public .... That is the real meaning of "prior art" in legal theory.... Society, speaking through Congress and the courts, has said "thou shalt not take it away."

Kimberly-Clark Corp. v. Johnson \& Johnson, 745 F.2d 1437, 1453-54 (Fed. Cir. 1984) (citations omitted) (emphasis added).

75. Despite its back-and-forth on how to interpret post-AIA Section 102, see supra Part IV, this guidance comes from the U.S. Patent and Trademark Office's Manual of Patent Examining Procedure. MPEP $\$ 2152$ (9th ed. Rev., June 2020), https://www.uspto.gov/web/offices/pac/mpep/s2152.html.

76. We recognize that patent examiners, more so than courts, may benefit from being able to quickly place a proffered reference into a formal category, as an initial matter. Examiners have to deal with voluminous amounts of information and are generally under time pressure. See, e.g., Mark A. Lemley, Rational Ignorance at the Patent Office, 95 Nw. U. L. REV. 1495, 1499-1500 (2001) (discussing the cost and time required to examine a patent); Janet Freilich, Patent Clutter, 103 IowA L. REv. 925, 964-65 (2018) (same); Michael D. Frakes \& Melissa F. Wasserman, Irrational Ignorance at the Patent 


\section{THE TRADE SECRECY STANDARD FOR PRIOR ART}

Grand principles like "available to the public" sound good. But what does it really mean for information to be public? When does an act of "disclosing" information make the information sufficiently public that patent law cannot ignore it? On the surface, these are difficult questions, but questions that we believe are and should be informed by trade secret law as expressed in the Defend Trade Secrets Act (DTSA) and the Uniform Trade Secrets Act (UTSA). ${ }^{77}$

Standard definitions of the terms "publication" and "public" equate publicness with deliberate, widespread dissemination of information in a way that makes the information accessible to all members of a community. ${ }^{78}$ But this is not the way courts think of publicness in prior art jurisprudence. Indeed, courts have used the precise phrase, "available to the public," to describe the effect of disclosures of information that, frankly, do not seem very public at all. ${ }^{79}$ This is because of important policy choices.

In this Part, we draw on trade secrecy concepts to explain these policy choices. The result is a definition of publicness that is different and more encompassing than traditional definitions of publicness. We also demonstrate that the trade secrecy concept of publicness appears to control in patent prior art cases as well.

Office, 72. Vand. L. Rev. 975, 978-79 (2019) (same); Shine Tu, Patenting Fast and Slow: Examiner Rejections and Applicant Traversals to Non-Prior Art Rejections, W. VA. Coll. L. RSCH. PAPER SERIES No. 2020-005 1 (Mar. 1, 2020).

77. Defend Trade Secrets Act of 2016, Pub. L. No. 114-153, 130 Stat. 376 (2016) (codified as amended at 18 U.S.C. $§ \S 1831$ to 1839 ); Unif. Trade Secrets Act $§ 1$ (Unif. L. Comm'n 1985).

78. For example, Merriam-Webster defines "public" as meaning, among other things, "exposed to general view" or "accessible to or shared by all members of the community.” MERRIAM-WEBSTER, https://www.merriam-webster.com/dictionary/public (last visited Apr. 9, 2021). It defines to "publish" as meaning, among other things, "to make generally known," "to disseminate to the public," or "to produce or release for distribution." MERRIAM-WEBSTER, https://www.merriam-webster.com/dictionary/public (last visited Apr. 9, 2021); see also Sharon K. Sandeen, Disclosure, in Research HANDBook On Information Law and Governance (Sandeen, S., Rademacher, C. Ohly, eds.) (Edward Elgar Publishing, Cheltenham, UK) (forthcoming); Sharon K. Sandeen, Disclosure, Publication, and the Public Domain, Akron L. REv. (forthcoming 2021).

79. Mark A. Lemley, Does "Public Use" Mean the Same Thing It Did Last Year?, 93 Tex. L. ReV. 1119, 1128 (2015). 


\section{A. $\quad$ The Trade Secrecy Standard for Publicness}

Trade secret law in the United States has evolved for over 180 years and was substantially refined in 1979 with adoption of the UTSA and its multi-part definition of a trade secret. ${ }^{80}$ In 2016, Congress borrowed the UTSA's definition of a trade secret when it enacted the Defend Trade Secrets Act of 2016 and for the first time created a parallel federal civil cause of action for trade secret misappropriation. ${ }^{81}$

The DTSA (and the UTSA) defines a trade secret as: (1) information that (2) "derives independent economic value, actual or potential," (3) "from not being generally known to, and not being readily ascertainable through proper means by, another person who can obtain economic value from the disclosure or use of the information"; and (4) is information "the owner ... has taken reasonable measures to keep ... secret." 82

Trade secret law does not create exclusive rights against the world. Instead, it creates a private cause of action against one who has engaged in trade secret "misappropriation." ${ }^{3}$ Misappropriation encompasses primarily the wrongful acquisition, disclosure, or use of another's trade secrets. ${ }^{84}$ This typically occurs when a person in lawful possession of the secret, such as an employee, discloses or uses the secret in violation of a duty of confidentiality or when someone acquires the secret by "improper means." ${ }^{85}$

But our focus isn't on the intricacies of a trade secret cause of action. Rather, it is on trade secret law's unique definitions of secrecy and publicness. Built into the definition of a trade secret is a relatively clear standard for what it means for information to be legally secret, on the one hand, or legally public, on the other.

This mechanism requires assessing two closely related issues. The first issue is whether the information is sufficiently secret-namely,

80. Sharon K. Sandeen, The Evolution of Trade Secret Law and Why Courts Commit Error when They Do Not Follow the Uniform Trade Secrets Act, 33 Hamline L. Rev. 493, 523 (2010).

81. The DTSA does not preempt state law claims, meaning a plaintiff can assert both simultaneously. 18 U.S.C. § 1838; see also Sharon K. Sandeen \& Christopher B. Seaman, Toward a Federal Jurisprudence of Trade Secret Law, 32 BERKELEY TECH. L.J. 829, 845 (2017).

82. 18 U.S.C. $\$ 1839$ (3). The principal difference between the DTSA and the UTSA language with respect to secrecy is that the UTSA uses the phrase "other persons" instead of "another person." Unif. Trade Secrets Act § 1(4) (Unif. L. Comm'n 1985).

83. RowE \& SANDEEN, supra note 19, at 253-54.

84. Id. (explaining various pathways for proving misappropriation).

85. Id.; see 18 U.S.C. $\$ \$ 1836(\mathrm{~b}), 1839(5),(6)$. 
whether it is "generally known" or "readily ascertainable" using proper means. The second issue is whether the putative owner of a trade secret (or the entity in lawful possession of $i^{86}$ ) has taken reasonable measures to maintain the information's secrecy. If either of these prongs fails, then the information is deemed public for purposes of trade secret law and thus not protectable. ${ }^{87}$

\section{Not generally known or readily ascertainable}

The first prong of trade secret law's secrecy versus public divide is whether the information has become "generally known" or "readily ascertainable through proper means" to "another person" who can obtain economic value from the disclosure or use of the information. ${ }^{88}$ The "generally known" or "readily ascertainable" concept provides a baseline for assessing information's publicness. If a disclosure, such as a publication in a prior patent, has rendered information "generally known" or "readily ascertainable," it is deemed public and not protectable. ${ }^{89}$ Deciding what is "generally known" or "readily ascertainable" for trade secrecy purposes requires a court to engage in a process that "is similar to a "prior art' search under patent law." alleged trade secrets with what was already known to others in the "applicable industry." ${ }^{\prime \prime 1}$ We will return to this analogy momentarily

86. The entity seeking to protect the information need not be the technical owner; it can be others in possession of the secret, such as a licensee. See $§ 1839$ (4); see also State ex rel. Lucas Cnty. Bd. of Comm'rs v. Ohio Env't Prot. Agency, 724 N.E.2d 411, 419 (Ohio 2000) (per curiam).

87. Our framing of the trade secrecy standard for prior art deals only with the question of publicness or secrecy of information-it does not require assessment of the "economic value" of the information, which is a critical issue in trade secret cases. This is important because, as we'll discuss in Part IV, if an inventor is deriving economic value from her invention, a separate doctrine that bars patentability regardless of secrecy may be triggered. On economic value, see Camilla A. Hrdy \& Mark A. Lemley, Abandoning Trade Secrets, 73 StAn. L. Rev. (forthcoming 2021).

88. 18 U.S.C. $\$ 1839(3)(\mathrm{B})$; see, e.g., T-N-T Motorsports, Inc. v. Hennessey Motorsports, Inc., 965 S.W.2d 18, 22 (Tex. Ct. App. 1998) ("The word 'secret' implies that the information is not generally known or readily available.").

89. This can happen as early as the motion to dismiss stage of litigation. See William Lynch Schaller, On Equipoise, Knowledge, and Speculation: A Unified Theory of Pleading Under the Defend Trade Secrets Act-Jurisdiction, Identification, Misappropriation, and Inevitable Disclosure, 27 J. InTELl. Prop. L. 137, 168-69 (2020) (explaining that courts will dismiss at the 12(b)(6) stage trade secret claims where the allegedly "secret" information is shown to be "in the public domain").

90. See RowE \& SANDEEN, supra note 19, at 93-94.

91. Id. 
when we discuss patent law's "printed publication" cases, but first we need to unpack trade secrecy's "generally known" or "readily ascertainable" concepts. They are slightly different and have to be assessed separately.

\section{a. "Generally known"}

The concept of "generally known" is closer to the common understanding of what it means for information to be made publicnamely, that it has to be widely disseminated. Thus, for example, if a trade secret has been fully disclosed in a United States patent or a universally accessible website, it will be deemed generally known and not protectable. ${ }^{92}$

Importantly, information can be deemed "generally known" even if it is not disclosed to members of the general public, so long as the information has become known to others, including experts in the field as well as potential competitors, who might realistically want to access the information and derive value from it. ${ }^{93}$ So, for example, the fact that a novice or lay person does not know the information doesn't necessarily mean it is not "generally known" for trade secret law purposes. ${ }^{94}$

\section{b. "Readily ascertainable"}

The "readily ascertainable" concept creates an additional hurdle. It extends trade secret law's baseline for publicness significantly beyond the common understanding.

Under the DTSA and most state trade secret laws, information is treated as public and not protectable if it is "readily ascertainable" through the use of "proper means." 95 "Proper means" is itself a term of art, encompassing methods such as working backwards from public sources or developing independently-anything that isn't considered "improper means," like espionage, trespass, or bribing an insider to reveal the information. ${ }^{96}$

92. Roger M. Milgrim, Milgrim on Trade Secrets $§ 1.03$ (2020).

93. 18 U.S.C. $\$ 1839(3)$; MILGRIM, supra note 92, § 1.03; see also, e.g., Hayden's Sport Ctr., Inc. v. Johnson, 441 N.E.2d 927, 933 (1982) (suggesting that the audience that matters for assessing secrecy in trade secret cases is "the general public," as well as "plaintiff's competitors").

94. See, e.g., Yield Dynamics, Inc. v. TEA Sys. Corp., 66 Cal. Rptr. 3d 1, $20-22$ (Cal. Ct. App. 2007) (discussing what qualifies as "generally known" under the California UTSA).

95. The DTSA adopts the additional "readily ascertainable" language, 18 U.S.C. $\S 1839$ (3), though not all states do. Cf. Cal. Civ. Code. $§ 3426.1(\mathrm{~d})$ (West 2012).

96. 18 U.S.C. $§ 1839(6)$. 
The general rule is that information is "readily ascertainable" (even if not generally known) so long as a person in the relevant field could discern it using "reasonable effort" and utilizing only legal means. ${ }^{97}$ For example, information might be deemed "readily ascertainable" if it could be found in trade journals or reference books, even if it is not clear people have actually accessed them, because they could potentially do so without too much effort. ${ }^{98}$

\section{Reasonable measures to maintain secrecy}

Information often fails the test of trade secrecy because it is generally known or readily ascertainable, but if it passes that test, that is not the end of the inquiry. To be legally secret for trade secret law purposes, information also has to be deliberately kept that way by the entity claiming rights in the information. For our purposes, the entity seeking to protect the information need not be the technical owner or even the entity that developed the information-it can be a licensee or potentially even a third party in possession of the secret. ${ }^{99}$

To quote the DTSA, the purported owner or possessor of the information must take "reasonable measures to keep [the] information secret." 100 Thus, if the owner of the trade secret, or the person claiming rights to the information, "failed to take affirmative steps to protect the secrecy of the [information]," then it will be deemed legally public for purposes of trade secret law and not amenable to trade secret protection even if it is not generally known or readily ascertainable. ${ }^{101}$

There are several rationales for the reasonable measures requirement. ${ }^{102}$ First, requiring efforts to maintain secrecy helps prove the

97. Flotec, Inc. v. S. Rsch., Inc., 16 F. Supp. 2d 992, 1000 (S.D. Ind. 1998).

98. See Unif. Trade Secrets Act $\$ 1$ cmt. (UNIF. L. Comm’n 1986) ("Information is readily ascertainable if it is available in trade journals, reference books, or published materials."); see also Art \& Cook, Inc. v. Haber, 416 F. Supp. 3d 191, 196 (E.D.N.Y. 2017).

99. See, e.g., Advanced Fluid Sys., Inc. v. Huber, 958 F.3d 168, 179 (3d Cir. 2020) (affirming rule).

100. 18 U.S.C. $\S 1839(3)$ (A). Under the UTSA, this requirement is referred to as the "reasonable efforts" requirement. Unif. Trade Secrets Act $\$ 1, \mathrm{cmt}$. We use the "reasonable measures" language of the federal DTSA, but we view these terms as synonymous, as did Congress. See H.R. ReP. No. 114-529, at 2.

101. MILGRIM, supra note $92, \S 1.03$.

102. Robert G. Bone, Trade Secrecy, Innovation and the Requirement of Reasonable Secrecy Precautions, in THE LAW AND TheORY OF TRAdE SECRECY: A HANDBOOK OF CONTEMPORARY RESEARCH 46, 49-50, 59-60 (Rochelle C. Dreyfuss \& Katherine J. Strandburg eds., 2011); Deepa Varadarajan, Trade Secret Precautions, Possession, and Notice, 68 Hastings L.J. 357, 362 (2017). 
trade secret is in fact secret and that it has economic value to the owner. ${ }^{103}$ Second, requiring efforts to maintain secrecy ideally places others on "notice" of the information's intended confidentiality. ${ }^{104}$ As Roger Milgrim puts it, the notice provided by the owner's secrecy precautions, such as a confidentiality ledger or a non-disclosure agreement, prevents others-including employees, licensees, contractors, or third-party passersby_from being unfairly "lull[ed] . . . into believing that the information would not be subject to an assertion of trade secret protection." 105 Notice protects others from unfairly relying on information they receive and believing it is free to use and disclose. After all, one cannot be expected to keep in confidence what one does not know is intended to be kept confidential. ${ }^{106}$

There is no bright-line rule for what constitutes "reasonable" measures to preserve information's secrecy because it depends upon the circumstances of each case. As one court put it:

The question of whether, in a specific case, a party has made reasonable efforts to maintain the secrecy of a purported trade secret is by nature a highly fact-specific inquiry. What may be adequate under the peculiar facts of one case might be considered inadequate under the facts of another. ${ }^{107}$

For example, in some contexts, sharing extensive amounts of information with employees, and even with outsiders, can be acceptable-so long as this sharing is essential to how the business operates and the company takes appropriate steps like making it clear the disclosure is intended to be confidential and placing the recipient under a legal duty not to further share the information. ${ }^{108}$

Although courts typically prefer that companies use explicit confidentiality contracts to protect their alleged trade secrets, ${ }^{109}$ unstated

103. Milgrim, supra note $92, \S 1.04$ (noting that secrecy measures may provide indirect evidence of actual secrecy).

104. Id.

105. Id.

106. See, e.g., David W. Slaby et al., Trade Secret Protection: An Analysis of the Concept "Efforts Reasonable Under the Circumstances to Maintain Secrecy", 5 SANTA CLARA CompUT. \& High TECH. L.J. 321, 328-29 (1989).

107. Elm City Cheese Co. v. Federico, 752 A.2d 1037, 1050 (Conn. 1999) (citation omitted). See generally Slaby, supra note 106, at 325.

108. Slaby, supra note 106, at 329-30 (discussing application of "reasonable efforts" requirement for disclosures to third parties).

109. David S. Almeling et al., A Statistical Analysis of Trade Secret Litigation in State Courts, 46 Gonz. L. REv. 57, 80-83 (2011) (showing that courts often assess whether a plaintiff used a confidentiality contract). 
assumptions about what is appropriate in the industry and context matter. For example, in a recent case, a U.S. district court held that a company's failure to force a former employee to return her electronic devices when she left her job did not demonstrate inadequate secrecy precautions on summary judgment, given that the employee had an implicit "responsibility not to use or disclose any of [the company's confidential] information." 110 The one thing that seems relatively certain is that doing absolutely nothing is insufficient. ${ }^{111}$

\section{B. $\quad$ The Trade Secrecy Standard at Work in Prior Art Case Law}

In patent law, the trade secrecy status of prior art, or something close to it, has been supplying the rule for what it means for a reference to be "available to the public" since at least the nineteenth century. Indeed, our review of the patent prior art case law shows the trade secrecy status of information is largely dispositive for deciding what counts as prior art under Section 102 of the Patent Act (both pre- and post-AIA).

We are not the first commentators to observe this symmetry in the development of patent prior art and trade secret law jurisprudence. ${ }^{112}$ Nor are we the first to advocate for the potential utility of trade secrecy concepts for patent law doctrine, generally. ${ }^{113}$ But so far as we know, we are the first to fully flesh out this symmetry in the case law and to explain its normative advantages.

What follows gives only an overview of the prior art case law, ranging from classic and oft-cited cases to more contemporary decisions of the Federal Circuit. However-with the exception of the jurisprudence concerning inventors' (and occasionally third parties') commercial use in secret-most of the prior art case decisions that we reviewed can be explained by application of the trade secrecy standard of publicness.

110. Vendavo, Inc. v. Long, 397 F. Supp. 3d 1115, 1138-39 (N.D. Ill. 2019).

111. Dicks v. Jensen, 768 A.2d 1279, 1285 (Vt. 2001) ("Because plaintiff has adduced no evidence that he took reasonable efforts to maintain the secrecy of the customer information, we hold, as a matter of law, that this customer list is not a trade secret.").

112. See generally Risdale Ellis, Subsequent Inventor's Patent Rights with Regard to an Invention Previously Made by Another Who Kept It Secret, 35 J. Pat. OfF. Soc'Y 259 (1953). See also, e.g., Note, Prior Art in the Patent Law, 73 Harv. L. Rev. 369, 373 (1959); Merges, supra note 59, at 1037 n.38; Lemley, supra note 79, at 1126.

113. See, e.g., Holbrook, supra note 1, at 193 ("Patent law could likely be better informed by a greater engagement with the law of trade secrecy in this regard."); Jonas Anderson, Secret Inventions, 26 BERKELEYTECH. L.J. 917, 921 (2011) (arguing that "trade secrets and patents should be viewed ... as complementary tools for policy makers"). 


\section{The "printed publication" case law}

"Printed publication" is one of the categories of prior art specified in Section 102 of the Patent Act. ${ }^{114}$ Based upon the statutory language, one might think courts would interpret the phrase in line with a traditional definition of what it means to "publish" something. ${ }^{115}$ We could envision, for instance, a strict definition, requiring distribution of physical copies that have been received by multiple people or at least indexed in a public place. ${ }^{116}$ But the courts have given "printed publication" a more expansive meaning that we argue is consistent with trade secret law's concepts of "generally known" and "readily ascertainable."

As Sean Seymore has observed, the Federal Circuit has refused to "subordinate substance to form" in the "printed publication" analysis. ${ }^{117}$ Instead, courts ask whether the reference is "accessib[le] to the interested public," 118 and, more specifically, whether it has been "disseminated or otherwise made available to the extent that persons interested and ordinarily skilled in the subject matter or art exercising reasonable diligence, can locate it." ${ }^{119}$ Importantly, as this quote shows, "publicness" for purposes of the printed publication bar is generally measured from the perspective of the "person having ordinary skill in the art" ("PHOSITA"). ${ }^{120}$ The PHOSITA's knowledge level is determined by a variety of factors, but she is generally charged with knowing sources that are available to members of the general public, as well as sources available only to experts in the field. ${ }^{121}$ The PHOSITA, as Sean Seymore writes, is a "lens" through which the court "views the prior art and the claimed invention." 122

Patent law's touchstone of "accessibility" to the "person interested in the art," is directly analogous to trade secret law's rule that information

114. 35 U.S.C. $\$ 102$ (a) (1).

115. "The roots of publish and publication both arise from the Latin publicare and publicatio, "to make public property, to place at the disposal of the community, to make public, to make generally known, to exhibit publicly, to publish a book, to confiscate."” Sean M. O'Connor, Distinguishing Different Kinds of Property in Patents and Copyrights, 27 Geo. Mason L. ReV. 205, 206 n.1 (2019).

116. Cf. Seymore, supra note 5, at 504-06.

117. Id. at 504, 508-09.

118. Id. at 496 .

119. Id. at 496 n.24 (quoting Bruckelmyer v. Ground Heaters, Inc., 445 F.3d 1374, 1378 (Fed. Cir. 2006)).

120. We discuss this issue further in Part IV.

121. Seymore, supra note 5 , at 512-13.

122. Id. at 513. 
loses its status as a trade secret once it has become generally known or readily ascertainable using proper means to another person who could obtain economic value from disclosure or use of the information. ${ }^{123}$ Indeed, because the two standards are very similar, they typically reach the same outcomes.

Not surprisingly, both patent prior art jurisprudence and trade secret law consider traditional forms of disclosures and publications, such as U.S. patents, legally public. ${ }^{124}$ The Federal Circuit itself has observed this analogy, citing to its patent prior art case law in a recent trade secret decision. The court held that an alleged trade secret was legally public, and not protectable under state trade secret law, because it had already been disclosed in a foreign patent. ${ }^{125}$

The harder "printed publication" cases provide a still more compelling illustration for the analogy to trade secret law. One of the most oft-cited examples is the Federal Circuit's decision in In re Hall, ${ }^{126}$ where a single doctoral dissertation in a library in Germany-which had not yet been indexed and had only recently been cataloguedcounted as a "printed publication" that barred a subsequent patent for the same chemical invention that was disclosed in the thesis. ${ }^{127}$ The court held the thesis was sufficiently "publicly accessible" because a person "interested in the art" could have found it exercising "reasonable diligence."128 This is analogous to trade secret law's "readily ascertainable" concept.

The "readily ascertainable" concept was at work again in In re Lister ${ }^{129}$ where the court held that a manuscript deposited with the U.S. Copyright Office was "publicly accessible," to the extent that it could be located by persons interested in the art exercising "reasonable

123. 18 U.S.C. $\$ 1839$ (3) (defining the term "trade secret" with respect to whether it is "generally known" or "readily ascertainable" to "another person who [could] obtain economic value from the disclosure or use of the information."); see also RowE \& SANDEEN, supra note 19, at 91-93.

124. See louis Altman \& Malla Pollack, 3 Callmann on Unfair Competition, Trademarks AND Monopolies $\$ 14: 27$ (4th ed. 2020) ("Publication of the secret destroys its value as such.”).

125. See Ultimax Cement Mfg. Corp. v. CTS Cement Mfg. Corp., 587 F.3d 1339, 1355-56 (Fed. Cir. 2009) ("Indeed, one of the primary purposes of patent systems is to disclose inventions to the public.").

126. 781 F.2d 897 (Fed. Cir. 1986).

127. Id. at 898 .

128. Id. at 899-900.

129. 583 F.3d 1307 (Fed. Cir. 2009). 
diligence." ${ }^{130}$ Although the court noted that time and expense might be required to view the manuscript at the Copyright Office, it found dispositive that "any member of the public" could potentially do so by submitting a proper request, or could even "hire someone local to inspect the manuscript on their behalf." ${ }^{131}$

Notably, courts use a similar analysis when interpreting the "patented" category of prior art. ${ }^{132}$ The Federal Circuit has held that foreign patents-which not unlike a German thesis can be hard to find-need to be "available to the public" as of the critical date to be counted as prior art, and interprets this phrase to mean reasonably accessible to the hypothetical person of ordinary skill in the art, and not deliberately kept secret. ${ }^{133}$ In more recent cases, the Federal Circuit used a similar analysis with respect to an article published on a website; ${ }^{134} \mathrm{a}$ fourteen-slide presentation that was displayed for around two days at a conference, ${ }^{135}$ and a product catalog displayed at an annual trade show. ${ }^{136}$

In the slide presentation case, In re Klopfenstein, ${ }^{137}$ the fourteen-slide presentation was only displayed on a billboard for two-and-a-half days

130. Id. at 1311-16 (quoting Kyocera Wireless Corp. v. Int'l Trade Comm'n, 545 F.3d 1340, 1350 (Fed. Cir. 2008)).

131. Id. at 1313-14. But see id. at 1317 (holding there was insufficient evidence to establish that the manuscript was available more than one year prior to patent filing). 132. The "patented" category refers to both U.S. and foreign patents, see 35 U.S.C. $\S 102$ (a) (1952) and 35 U.S.C. $\$ 102$ (a) (1) (2018), but is more likely to trigger publicness issues with respect to foreign patents because they can be harder to access than domestic patents, which have long been searchable on the website of the U.S. Patent and Trademark Office (USPTO). See Official Gazette, USPTO, https:/ /www.uspto.gov/learning-and-resources/official-gazette (last modified Jan. 5, 2021).

133. See Merges \& Duffy, supra note 25, at 427. Compare In re Carlson, 983 F.2d 1032, 1037 (Fed. Cir. 1992) (holding German design patent was "available to the public" under Section 102(a)), with In re Ekenstam, 256 F.2d 321, 323-25 (C.C.P.A. 1958) (holding a foreign patent that is "deliberately kept secret" is not prior art).

134. Voter Verified, Inc. v. Election Sys. \& Software, Inc., 698 F.3d 1374, 1379-81 (Fed. Cir. 2012) (holding article maintained on "Risks Digest" website was a prior art "printed publication" as defined by 35 U.S.C. $§ 102$ (b) since it was "sufficiently accessible to the public interested in the art").

135. In re Klopfenstein, 380 F.3d 1345, 1347-50 (Fed. Cir. 2004).

136. GoPro, Inc. v. Contour IP Holding LLC, 908 F.3d 690, 693 (Fed. Cir. 2018) (holding a catalog that disclosed a digital camera, which was displayed at a trade show focused on action sports vehicles and accessories, was a Section 102(b) "printed publication" because "persons interested and ordinarily skilled in the subject matter... exercising reasonable diligence, can locate it." (quoting Kyocera Wireless Corp. v. Int'l Trade Comm'n, 545 F.3d 1340, 1350 (Fed. Cir. 2008))).

137. 380 F.3d 1345 (Fed. Cir. 2004). 
at one conference and less than one day at another conference. ${ }^{138}$ But the Federal Circuit held the presentation was "publicly accessible" because it was "shown to a wide variety of viewers, a large subsection of whom possessed ordinary skill" in the field to which the invention pertained. ${ }^{139}$ The court noted that for those specially skilled people, copying the information in the presentation "would have been a relatively simple undertaking." 140 Ease of copying was a factor, with the court noting that " $[\mathrm{t}]$ he more complex a display, the more difficult it will be for members of the public to effectively capture its information," while the "simpler a display is, the more likely members of the public could learn it by rote [memory] or take notes adequate enough for later reproduction." 141

Trade secret law has a similar standard to determine whether information like that in In re Klopfenstein is rendered too public to be protectable: the "generally known" and "readily ascertainable using proper means" tests. Just like In re Klopfenstein, a court in a trade secret case would have assessed whether a person in the field could discern the information without expending too great an effort. ${ }^{142}$ Importantly, this assessment has nothing to do with obviousness. It is about how easy it would have been for someone to access the information, not how easy it would have been for them to come up with the invention contained therein.

While the question of whether information is readily ascertainable depends upon the circumstances, courts in trade secret cases involving the same sort of information as in In re Klopfenstein would have found that the disclosures rendered the information public. The reason is that information can be denied trade secret status even if it takes some effort to find it. For example, in a recent trade secret case, a federal court in the Northern District of Illinois held that coupon codes that were "imbedded in [plaintiff's] website" were "available to the public" and not protectable under trade secret law, because no "subscription

138. Id. at 1351 .

139. Id. at 1350 .

140. Id. at 1352 .

141. Id. at 1351 .

142. Cf. Morlife, Inc. v. Perry, 66 Cal. Rptr. 2d 731, 735-36 (Cal. Ct. App. 1997) (holding that information regarding customers of a commercial roofing business was not "readily ascertainable" because the identities of customers in need of commercial roofing services was "only discoverable with great effort"). 
or user fee [was] necessary to access the coupon codes," and the codes could thus potentially be discerned. ${ }^{143}$

One might object that trade secret law's standard is too fact specific to apply in the patent context. After all, whether a disclosure counts as a "printed publication" is supposed to be a question of law. ${ }^{144}$ But the reality is that patent prior art cases are also highly fact dependent, as evidenced by the fact that similar fact patterns can reach distinct outcomes.

For example, in Lockheed Aircraft Corp. v. United States, ${ }^{145}$ the U.S. Court of Claims (whose jurisdiction was later assumed by the Federal Circuit) held that letters written to the U.S. Navy regarding research progress that were distributed in confidence to around thirty industry participants did not count as a "printed publication" and thus did not enter the prior art. ${ }^{146}$ Although seemingly inconsistent with In re Klopfenstein, this holding is easy to understand from the perspective of trade secret law. The information in the letters was disclosed to several entities, but it was not "readily ascertainable" using "proper means"given that it was treated as confidential by the United States government, and all the entities who received it treated it that way. ${ }^{147}$ Indeed, if someone got access to the letter by circumventing their duty of confidentiality, they would have been exposed to a trade secret claim. ${ }^{148}$ Supreme Court case law in the government context buttresses the conclusion that such a letter could have been provided to the government under an assurance of privacy. ${ }^{149}$

143. CouponCabin, Inc. v. PriceTrace, LLC, No. 18-C-7525, 2019 WL 1572448, at *3 (N.D. Ill. Apr. 11, 2019); cf. Compulife Software Inc. v. Newman, 959 F.3d 1288, 1313-15 (11th Cir. 2020) (holding a compilation trade secret whose individual parts were on a public accessible website but that was only discernable as a whole by using a computer, was not generally known or readily ascertainable to "another person" using proper means); Religious Tech. Ctr. v. Netcom On-Line Commc'n Servs., Inc., 923 F. Supp. 1231, 1255 (N.D. Cal. 1995) (holding that a temporary, fleeting publication of documents on a website was not enough to show "without evidence that the secrets [had] become generally known" to people in the field).

144. Seymore, supra note 5 , at 505 .

145. 553 F.2d 69 (C.t. Cl. 1977) (per curiam).

146. Id. at 77 .

147. Id. at 74 .

148. Cf. Evans Cooling Sys., Inc. v. Gen. Motors Corp., 125 F.3d 1448, 1452 (Fed. Cir. 1997); see also infra notes 301-03 and accompanying text (describing the Evans case in detail).

149. Compare Ruckelshaus v. Monsanto Co., 467 U.S. 986, 1011-12 (1984) (holding that a party who submits trade secrets to the federal government may have a takings 
Lockheed illustrates something very important about the patent prior art "printed publication" cases. Although the focus is on "public accessibility," the courts in these cases are assessing more than just "de facto "public accessibility. They are assessing whether the information is being treated by its possessor as confidential. The fact that the Navy distributed its letter to industry participants under circumstances that gave rise to an implied duty of confidentiality was probably dispositive. ${ }^{150}$ What this indicates to us is that, just like in trade secrecy cases, courts in these non-traditional "printed publication" cases are assessing whether the person or entity in possession of the putative prior art reference has taken "reasonable measures" to maintain the information's secrecy. ${ }^{151}$

The reasonable efforts analysis arises less frequently in "printed publication" cases than it does in the activity (e.g., "public use") cases for the obvious reason that publications will more often fail the basic secrecy prong by rendering information "generally known" or at least "readily ascertainable" to others. But even in "printed publication" cases, the courts in patent cases do assess whether reasonable secrecy precautions were undertaken. Indeed, in In re Klopfenstein, the Federal Circuit assessed "protective measures" as a specific factor in its analysis. ${ }^{152}$ As Seymore observes, especially post-Klopfenstein, the court is more likely to find a reference is not a printed publication if protective measures were taken to keep it secret and vice versa. ${ }^{153}$ The effect is to actively "encourage" inventors who want to present their

claim when the government "had explicitly guaranteed to [submitters] an extensive measure of confidentiality and exclusive use"), with Gal-Or v. United States, 113 Fed. Cl. 540, 554-55 (2013) (holding that an inventor who disclosed information to the government without indicating it was confidential could not claim trade secret protection).

150. See Lockheed, 553 F.2d at 74 n.5 (noting that the defendant's assertion that the confidential document was public was "not supported by precedent," even though the court did not decide the issue).

151. 18 U.S.C. $\$ 1839(3)$.

152. In re Klopfenstein, 380 F.3d 1345, 1351-52 (Fed. Cir. 2004); see also Jockmus v. Leviton, 28 F.2d 812, 814 (2d Cir. 1928) (holding that a trade catalogue distributed to French customers of a German firm, with around 1,000 going out, was printed publication prior art, given that it was not "intended to be kept secret; its whole purpose was to be spread broadcast as far as possible"); GoPro, Inc. v. Contour IP Holding LLC, 908 F.3d 690, 695 (Fed. Cir. 2018) (holding that a catalog displayed at a trade show was a "printed publication" in part because it "was disseminated with no restrictions and was intended to reach the general public").

153. In re Klopfenstein, 380 F.3d at 1352. 
work, and thereafter apply for a patent, to take secrecy precautions, in order "to create the reasonable expectation that the information will not be copied." 154 Otherwise, they are likely to trigger the one-year period in which to file a patent application.

It is also worth pointing out that the Federal Circuit's controversial inherency case law can arguably be explained by application of a "readily ascertainable" inquiry, combined with an assessment of "reasonable measures" to retain secrecy. For example, the Federal Circuit has held that even relatively hidden features of a disclosuresuch as trace amounts of a metabolite produced in a body-can be counted as "inherently" present in the prior art, even if they aren't "expressly" revealed to the person of ordinary skill. ${ }^{155}$ This is consistent with the notion that publicness can encompass disclosures that would take a certain amount of effort to discern, and that aren't being kept deliberately secret.

To conclude, we think the analysis applied in "printed publication" cases closely tracks the analysis applied in trade secrecy cases. We discuss the normative implications of this similarity in Part IV. But first, we discuss so-called "activity prior art," where the analogy is even more compelling and illustrates the extraordinary significance of "reasonable measures" to maintain secrecy for deciding whether a reference is public and constitutes prior art.

\section{The "public use" case law}

Pursuant to AIA Section 102, an invention is not novel if it is in "public use" prior to the patent application's filing date. Pre-AIA, the invention could not be "known or used by others" in the United States prior to the invention date, or in "public use" by anyone more than one year before patenting. ${ }^{156}$

Activity prior art-prior art that consists of alleged "public use" of the invention by the inventor or third parties, or "on sale" events such as the sale or offer for sale of a product embodying the claimed invention-is

154. Seymore, supra note 5, at 514-15.

155. Schering Corp. v. Geneva Pharms., Inc., 339 F.3d 1373, 1375-77 (Fed. Cir. 2003); see also Martin Adelman et al., Patent Law in a Nutshell 108 (2013); cf. Dan L. Burk \& Mark A. Lemley, Inherency, 47 WM. \& MARY L. Rev. 371, 374 (2005) (arguing that the inherency doctrine is based on the notion that even if certain information isn't in the public domain, "the public already gets the benefit of the claimed element or invention").

156. See supra Part I. 
very important for how patents are judged and invalidated. As Stephen Yelderman has recently shown, activity prior art is the most common form of prior art used in novelty invalidations in the district courts. ${ }^{157}$ An obvious reason for this is that litigants in patent cases have more time and resources to look for these types of prior art than do patent examiners.

Including activity prior art in the novelty (and nonobviousness) inquiries makes sense. Prior use, or even prior knowledge, of an invention can make information about an invention just as accessible to others as a traditional publication. Indeed, using an invention in plain view of a passerby arguably makes it more public than a description of the invention in a dissertation buried in a library (especially if the dissertation is in German).

Even more so than in the printed publication cases, the standard of publicness applied to activity prior art-particularly "known or used by others" and "public use" $\operatorname{cases}^{158}$ - resemble that of trade secret law. Courts virtually uniformly assess whether information about the invention that is the subject of prior use or knowledge was deliberately kept confidential and whether the protective measures taken were reasonable under the circumstances. ${ }^{159}$

The obvious reason for the frequency of the reasonable measures analysis in activity prior art cases, as compared to "printed publication" and "patented" cases, is that inventions can be known or used without making the details visible to others. This is harder to do in a printed medium, where the reference will likely just fail the basic secrecy prong, by rendering information generally known or at least readily ascertainable using proper means. ${ }^{160}$

Courts' attention to secrecy precautions in the activity prior art case law dates from the original prior art category as it existed in the first Patent Act of 1790. The Patent Act of 1790 limited patents to inventions that were "not before known or used." 161 Similarly, the

157. Note that Yelderman found activity prior art to make up the majority of prior art in the district courts, but not at the USPTO or the Patent Trial and Appeals Board (PTAB). See Yelderman, supra note 14, at 860 (finding "the majority of anticipation invalidations (52\%) relied on prior art classified as activities").

158. We discuss the "on sale" cases separately below.

159. See cases cited in note 168, infra.

160. Cf. Lockheed Aircraft Corp. v. United States, 553 F.2d 69, 74 (Ct. Cl. 1977) (per curiam).

161. See Patent Act of 1790, ch. 7, § 1, 1 Stat. 109, 109-10 (repealed 1793). 
Patent Act of 1952 (which, as explained in Part I, is still in effect for some patents) provides that no patent will be available if the invention was "known or used by others" before the invention date. ${ }^{162}$

The cases establish that "known or used" implies some degree of publicity related to the lack of security measures. ${ }^{163}$ We think the standard boils down to whether the information was being kept as a trade secret or not, and in particular whether the entity charged with knowing or using the information was taking sufficient secrecy precautions.

The Fifth Circuit's decision in Rosaire v. Baroid Sales Division, National Lead Co., ${ }^{164}$ which was decided prior to the creation of the Federal Circuit, is a good example. ${ }^{165}$ A close read of the decision shows that the court construed pre-AIA Section 102's phrase "known or used by others" to encompass a trade secrecy-like standard of publicness. The critical finding was that Teplitz, an employee at another oil company, had been using the same oil prospecting method that the inventors (Rosaire and Horvitz) later tried to patent, and that this prior use rendered the method "known or used by others" prior to the invention date. ${ }^{166}$ Importantly, the court found that Teplitz and his employer failed to take sufficient secrecy precautions regarding the method, noting: "[t]he work was performed in the field under ordinary conditions without any deliberate attempt at concealment or effort to exclude the public and without any instructions of secrecy to the employees performing the work." 167

The "public use" category of prior art provides an even richer source of decisions demonstrating the importance of measures to preserve secrecy in the prior art analysis. Indeed, the Federal Circuit currently defines public use as "any use of [the claimed] invention by a person other than the inventor who is under no limitation, restriction or obligation of secrecy to the inventor." 168 The outcome in these cases

162. 35 U.S.C. $§ 102$ (a) (1952).

163. Cf. Craig NARd, The Law of Patents 280-81 (3d ed. 2014).

164. 218 F.2d 72 (5th Cir. 1955).

165. Id. at 74-75 (explaining that no precedent requires an affirmative act to make the public aware of an invention).

166. Id. at 73-74 (holding the evidence was sufficient to show the proposed invention was publicly known or used before patented).

167. Id. at 74-75 (explaining the court, and patent law, does not require public knowledge to be shown to the public).

168. Lough v. Brunswick Corp., 86 F.3d 1113, 1119 (Fed. Cir. 1996) (quoting In re Smith, 714 F.2d 1127, 1134 (Fed. Cir. 1983)); see also In re Blaisdell, 242 F.2d 779, 783 (C.C.P.A. 1957) (explaining that public use includes "necessarily expos[ing the 
often centers on whether the inventor permitted others to use her invention without placing them under any obligation of confidentiality. ${ }^{169}$

The origin of this seemingly counterintuitive notion of what makes a use "public" is usually traced to the Supreme Court's holding in Egbert v. Lippman. ${ }^{170}$ In Egbert, the inventor of an improved corset spring (Samuel Barnes) gave two samples of the invention to Francis Lee Egbert (Barnes' then girlfriend and eventual wife). ${ }^{171}$ She wore them for more than two years before Barnes applied for a patent, and they allegedly showed and explained the corset spring to a friend, Joseph Sturgis, when he visited their house for dinner. ${ }^{172}$ Even though the spring was sewn into a corset and therefore, by its nature, was not visible to the public, the Court held it was in "public use" because it was given "to another" (to Egbert and to Sturgis) "to be used" by them "without limitation or restriction, or injunction of secrecy." 173

This holding baffled the dissenting Justice Miller, who wrote he was at "a loss to know the line between a private and a public use." ${ }^{174}$ But the trade secrecy standard explains how the Egbert Court drew the line. The Court's concept of public use was any sharing of the invention with another for use, without placing them under an "injunction of secrecy." 175 Use of the phrase "injunction of secrecy" is unlikely to be a coincidence because it also appeared in contemporary trade secret cases to refer to a duty of confidentiality that might give rise to an injunction. ${ }^{176}$ In sum, the corset spring was not the subject of reasonable efforts to maintain its secrecy, given how liberally Barnes

\footnotetext{
invention] to public view" without limitation); In re Smith, 714 F.2d at 1134 (noting that "public use" is "any use of [an] invention by a person other than the inventor who is under no limitation, restriction or obligation of secrecy to the inventor"); Petrolite Corp. v. Baker Hughes Inc., 96 F.3d 1423, 1425 (Fed. Cir. 1996) (same).

169. Barry v. Medtronic, Inc., 230 F. Supp. 3d 630, 653 (E.D. Tex. 2017), aff'd, 914 F.3d 1310 (Fed. Cir. 2019).

170. 104 U.S. 333, 336 (1881) (discussing the scope of public use).

171. Id. at 335,337 .

172. Id.

173. Id. at 336-37.

174. Id. at 339 (Miller, J., dissenting) (arguing the public would be ignorant of this hidden invention in the corset and the patent should not be barred).

175. Id. at 336 (majority opinion).

176. See, e.g., Cincinnati Bell Foundry Co. v. Dodds, 10 Ohio Dec. Reprint 154, 15455 (Super. Ct. 1887) (explaining an inventor selling a trade secret process is entitled protection from disclosure).
} 
shared it with his girlfriend and house guests, without first placing them under an obligation of confidentiality. ${ }^{177}$

We can debate whether this was the correct decision from the perspective of modern domestic relationships, given that a duty to maintain secrecy does not necessarily have to be written down. A duty to maintain secrecy can often be inferred where the "relationship between the parties to the disclosure" indicates an intent to keep the information confidential. ${ }^{178}$ By today's mores (if not the nineteenth century's), the trade secrecy standard might have been met in Egbert because the most public part of the disclosure was to the inventor's domestic partner. ${ }^{179}$ On the other hand, this would not justify the disclosure to Sturgis, which did not involve a promise of confidentiality, express or implicit. ${ }^{180}$

Other cases from the same period indicate that courts thought of secrecy in similar ways-requiring deliberate efforts to conceal the invention to keep it from being treated as public. For example, just a few years after Egbert, the Supreme Court again denied a patent for an invention that the inventors had used more than two years prior to filing a patent. Citing its opinion in Egbert, the Court held that-even though the inventive design feature was effectively "hidden from view" since it was inside the safe, and revealing it would have required "destruction of the safes"-the inventors had not made deliberate efforts at concealment. ${ }^{181}$ Rather, like Barnes, they'd simply relied on the inherent nature of their safe designs to maintain the secrecy of the invention. Like in a trade secret case, where zero efforts to maintain

177. Egbert, 104 U.S. at 335-37 (acknowledging the inventor gave his device to another without limitation).

178. See Restatement (ThiRd) of Unfair Competition $\$ 41$, cmt. b (Am. L. Inst. 1995) (explaining that courts recognize a duty to refrain from disclosure in some "confidential relationship[s]").

179. Egbert, 104 U.S. at 335-36. As Kara Swanson has observed, the Egbert Court's impression that this was a "public" disclosure of information may have been influenced by contemporary ideas about the nature of a nonmarital sexual relationship. Kara Swanson, Corset, in A History of Intellectual Property in 50 Objects 89, 91, 94-95 (Claudy Op Den Camp \& Dan Hunter eds., 2019) (describing the social norms of a close relationship at the time). Because Egbert was Barnes' "intimate friend" rather than his wife, an express confidentiality agreement was deemed necessary to ensure her silence. $I d$. at 94 .

180. Egbert, 104 U.S. at 335-36.

181. Hall v. Macneale, 107 U.S. 90, 97 (1883) (asserting the legitimate use of a private safe was not concealment). 
secrecy will disqualify an owner from enforcing trade secret rights, this simply was not enough. ${ }^{182}$

The trade secrecy standard sheds still more light when prior art activity arises within an employment setting, where courts must assess whether a company has exercised sufficient secrecy precautions with respect to its own employees. In trade secret law, it is well established that a firm may share its secrets with employees under an express (or implied) obligation to maintain secrecy, without sacrificing trade secret status. ${ }^{183}$ But when a firm shares that same information without first ensuring its employees owe an obligation of secrecy, a finding of insufficient secrecy precautions and a loss of trade secret status is likely to follow. ${ }^{184}$

The same principles are at work in the patent prior art cases involving sharing with employees: when a firm shares an invention with employees without taking secrecy precautions, even an otherwise internal disclosure can render the invention effectively public enough to enter the prior art. For example, in Electric Storage Battery Co. $v$. Shimadzu, ${ }^{185}$ the inventor, a firm named Shimadzu, sought and obtained patents for a machine and process that the defendant, Electric Storage Battery, had been using in its business for more than two years before Shimadzu filed for the patents. ${ }^{186}$ Although Electric Storage Battery had not deliberately disclosed the technology to the public, the Supreme Court concluded that its "ordinary" commercial usage was "public" for prior art purposes, and that Shimadzu's patents were thus invalid. ${ }^{187}$ The Court reasoned that the "machine, process, and product" had become "well known to the employees in the plant" and "[few] efforts were made to conceal them from anyone who had a

182. See, e.g., Abrasic 90 Inc. v. Weldcote Metals, Inc., 364 F. Supp. 3d 888, 898 (N.D. Ill. 2019) (holding a company's failure to protect its trade secrets likely renders trade secret claims invalid).

183. Kewanee Oil Co. v. Bicron Corp., 416 U.S. 470, 475 (1974) (explaining a trade secret is maintained when shared with another in confidence); see also RESTATEMENT (FIRST) OF TORTS $\$ 757$ (AM. L. INST. 1939) (explaining that trade secret disclosure can be protected by privilege and confidence).

184. See, e.g., Dicks v. Jensen, 768 A.2d 1279, 1282, 1284-85 (Vt. 2001).

185. 307 U.S. 5 (1939).

186. Id. at 20 (observing that no attempt was made to conceal the process).

187. Id. (holding that unless purposely concealed the commercial process was public); see also id. ("This use, begun more than two years before Shimadzu applied for patents $1,584,150$ and 1,896,020, invalidated the claims in suit."). 
legitimate interest in understanding them."188 Because the firm's employees were under no obligation to keep the invention secret, they could have easily leaked it to the public at any time. ${ }^{189}$

The Federal Circuit has built on the Supreme Court's holdings in Egbert and Shimadzu, deriving the definition of "public use" mentioned above. ${ }^{190}$ It described the public use rule in a 2013 case thus: "our case law understandably focuses on the limitations, restrictions, or secrecy obligations associated with a purported public use .... The degree of confidentiality necessary to avoid a finding of public use naturally depends on the circumstances." 191

The court made this rule statement in a patent dispute between two pharmaceutical companies. And yet the court's statements could have been cut out of a trade secret opinion by simply replacing the words "public use" with "trade secrecy-destroying event." While the language used is different, the effect is the same as trade secret law's reasonable measures requirement. ${ }^{192}$

Of course, the trade secrecy standard of reasonable measures can go both ways. If the inventor does take sufficient secrecy precautions-and the information otherwise meets the standard of trade secrecy-then the reference will not be considered prior art. This explains patent prior art cases that appear contrary to Egbert and its progeny, where courts found prior use not to be sufficiently public. ${ }^{193}$

For example, Moleculon Research Corp. v. CBS, Inc. ${ }^{194}$ involved the invention of the Rubik's Cube, a three-dimensional puzzle capable of

188. Id. (stressing that a process is public if available and not purposely concealed). 189. Id. (implying the lack of concealment publicly exposed the process to anyone with legitimate interest).

190. See, e.g., Lough v. Brunswick Corp., 86 F.3d 1113, 1119 (Fed. Cir. 1996) (explaining that an invention is public when an inventor fails to conceal it in the given circumstances).

191. Pronova Biopharma Norge AS v. Teva Pharms. USA, Inc. 549 F. App’x 934, 940 (Fed. Cir. 2013) (citations and quotations omitted).

192. 18 U.S.C. $§ 1839$ (3) (requiring reasonable measures to conceal a trade secret); see also RowE \& SANDEEN, supra note 19, at 199-201.

193. Another pre-AIA category where the trade secrecy standard seems to apply is $\S 102(\mathrm{~g})$ prior inventor prior art. A similar rule applied: the prior inventor's activity was not prior art if it had been "abandoned, suppressed, or concealed," which should rationally be interpreted to exclude any prior invention that was deliberately kept as a trade secret. See Ellis, supra note 112, at 268-74 (describing situations in cases where inventions were secretly used but not held to be public use); see also 35 U.S.C. § 102(g) (2006) (protecting pre-AIA patent rights for a first inventor).

194. 793 F.2d 1261 (Fed. Cir. 1986). 
rotational movement. ${ }^{195}$ The inventor, Larry D. Nichols, was employed as a research scientist for the patentee, Moleculon. Moleculon obtained a patent on the Rubik's Cube with Nichols named as the inventor, and eventually was in the position of having to enforce it against CBS. ${ }^{196}$ As part of its defense, CBS argued that Nichols had made an invalidating public use of the invention by discussing and sharing a prototype with others more than a year before the subject patent application was filed. ${ }^{197}$

The Federal Circuit ultimately held in favor of the patentee, rejecting CBS's public use argument. ${ }^{198}$ CBS's alleged public use was based on Nichols' decision to share a prototype of the cube (which he usually kept at home) with select individuals, including "a few close friends" and a colleague. ${ }^{199}$ The most public incident occurred when Nichols brought the prototype into his office at work and placed it on his desk. The president of Moleculon "entered Nichols' office and happened to see the model sitting on his desk" and "expressed immediate interest in the puzzle," prompting Nichols to explain its workings, and eventually leading to the company's decision to patent and commercialize it. ${ }^{200}$

When we consider the facts of Egbert and Shimadzu, the sequence of events in Moleculon sounds public enough. But trade secret law's more nuanced reasonable efforts assessment reveals what the Moleculon decision was really about. While it is true that Nichols explained his puzzle to a few close colleagues and with his boss when asked, "the personal relationships and other surrounding circumstances" made this sharing reasonable in context. ${ }^{201}$ As the court put it, Nichols "never used the puzzle" and never "permitted" anyone else to use it "in a place or at a time when he did not have a legitimate expectation of privacy and of confidentiality." Moreover, those whom he allowed to use the puzzle had no "basis for inferring that the puzzle was being given over by Nichols for their free and unrestricted use." ${ }^{02}$

195. Id. at 1263 .

196. Id.

197. Id. at 1263,1265 .

198. Id. at 1265-67 (explaining the inventor shared private use of the invention under his control).

199. Id. at 1263 .

200. Id.

201. Id. at $1265-66$.

202. Id.; cf. Beachcombers v. WildeWood Creative Prods., Inc., 31 F.3d 1154, 1160

(Fed. Cir. 1994) (holding disclosure of improved kaleidoscope invention at a house 
Moleculon, like Egbert before it, reflects courts' assumptions about relationships. The Moleculon court viewed an inventor sharing his invention with work colleagues as less public than an inventor sharing his invention with his dinner guest and girlfriend (not-yet-wife). These are precisely the sorts of context-specific factors assessed in trade secret cases when applying the reasonable measures requirement. Through a trade secrecy lens, it seems clear the court concluded that Nichols had engaged in reasonable, albeit imperfect, efforts to maintain the secrecy of his invention. ${ }^{203}$ Because Nichols was reasonably preserving his invention as a trade secret, it wasn't prior art against his company's (or anyone's) later attempt to get a patent.

In a recent case, BASF Corp. v. SNF Holding Co., ${ }^{204}$ albeit decided under pre-AIA law, the Federal Circuit confirmed that trade secrecy status matters-especially for third-party prior art. The prior art event was knowledge and use of a process by a third party (Celanese), which had extensively used the process in its U.S. plant for years before BASF's patent application was filed. ${ }^{205}$ The district court invalidated BASF's patent on the process, finding Celanese's activities constituted pre-AIA Section 102(a) "known or used by others" and Section 102(b) "public use," 206 stating that whether the activity was "secret or confidential is immaterial." 207

The Federal Circuit reversed, confirming that Celanese's efforts at secrecy-in particular "the existence of relevant confidentiality agreements" with employees and visitors to the plant, and "the degree to which they were honored"- -were absolutely material, and could end up being dispositive. ${ }^{208}$ However, because the parties disagreed on whether Celanese's practices met the confidentiality standards of prior

party hosted by the designer and attended by twenty to thirty guests was "public use," given that the designer "made no efforts to conceal the device or keep anything about it secret").

203. Moleculon, 793 F.2d at 1265-66; see also Rockwell Graphic Sys., Inc. v. DEV Indus., Inc., 925 F.2d 174, 180 (7th Cir. 1991) (explaining the impracticality of perfect security).

204. 955 F.3d 958 (Fed. Cir. 2020).

205. Id. at 962 (describing evidence of the third-party giving tours of the plant, which exposed the secret process to the public).

206. Id. (explaining that the district court upheld the public use bar).

207. Id. at 962 (quoting BASF Corp. v. SNF Holding Co., No. 4:17-cv-00251-RSBBWC 1, 22 (S.D. Ga. 2018) (lower court summary judgment order)).

208. BASF, 955 F.3d at 965-66 (citing Elec. Battery Storage Co. v. Shimadzu, 307

U.S. 5, 20 (1939) (relying on efforts to purposefully conceal an invention)). 
cases like Shimadzu (not enough) and Moleculon (enough), summary judgment was inappropriate. ${ }^{209}$ In sum, the outcome boiled down to a textbook inquiry into the reasonableness of the company's secrecy precautions.

\section{Exceptions to the Trade Secrecy Standard}

The informed reader is likely at this point to object that a trade secrecy standard for patent prior art is inconsistent with a significant segment of existing patent prior art jurisprudence. However, as we show below, for the most part, these exceptions do not illustrate a divergent idea of "publicness." Rather, they are based on other considerations separate from publicness. More generally, the existence of exceptions from the general rule does not dilute the trade secrecy standard's explanatory power. To the contrary, the fact that there are some outliers only tends to prove that trade secrecy qualifying uses of an invention don't usually count as patent prior art-unless a policy other than publicness is at play. What is more, the most important of the exceptions to the trade secrecy standard is ironically generated by the existence of trade secret law itself-specifically, by courts' understanding that trade secrecy is an alternative to patent law, and the inventor is supposed to have to choose between the two.

\section{When failing trade secrecy doesn't mean public}

For important public policy reasons, there is case law where a reference (the disclosure event) is fully public-obviously not a trade secret-and yet courts hold the disclosure not to be in the prior art. The principal example is the "experimental use" defense as expressed in cases like Elizabeth v. Pavement Co. ${ }^{210}$ There, the inventor had actually laid down pavement on an open city street to test whether his invention worked. The Supreme Court held that, despite its publicness, this was not barring "public use" because it was done by the inventor only "by way of experiment, and in order to bring the invention to perfection."211

The experimental use defense is, we think, a minor counterpoint to the trade secrecy standard for publicness designed to address a countervailing policy consideration; namely, the need of inventors to

209. Id. (questioning whether the evidence supported that concealment was sufficient for protection of the patent).

210. 97 U.S. 126, 129, 135 (1877) (explaining that the inventor was still constructing the invention).

211. Id. at 134 (describing an inventor's limitation on testing certain inventions). 
test public-facing inventions before commercializing them. In applying the defense, courts assess a variety of factors besides publicness, including "the necessity for the testing or evaluation" and "whether there was payment for the use." 12 They also assess factors that are highly consistent with the trade secrecy analysis, such as "whether the inventor monitored the use and kept a laboratory notebook or other experimental records... and whether there was a confidentiality agreement." 13 In other words, experimental use is definitely a potential exception to the general rule, but its fact-specific and narrow application means that most uses of inventions not meeting the trade secrecy standard will be deemed public.

\section{When maintaining trade secrecy is still public}

The bigger body of exceptions to the trade secrecy standard for patent prior art involves the secret utilization of inventions prior to patenting that are nonetheless deemed public for prior art purposes.

\section{a. On sale bar}

The first exception is Section 102's "on sale" bar, which provides that a claimed invention will not be novel if it was "on sale" before the relevant date. ${ }^{214}$

In one sense, the on sale bar is an affirmation of the trade secrecy standard for patent prior art. Most conceivable sales of an invention will probably fail the trade secrecy standard because sale of the invention will destroy its trade secrecy status. ${ }^{215}$ Products sold on the open market are often visible or can be easily reversed engineered, and thus are difficult to keep as trade secrets. As one court put it: " $[w]$ hether viewed though the rubric of 'not secret' or 'not subject to reasonable efforts at maintaining secrecy,' it should go without saying

212. Lough v. Brunswick Corp., 103 F.3d 1517, 1521 (Fed. Cir. 1997) (Newman, J., dissenting).

213. Id. at 1519-21 (dissenting from the en banc denial and providing factors to determine if inventive activity was experimental in nature).

214. Compare 35 U.S.C. $§ 102(a)(1)$ (2018) (effective filing date), with 35 U.S.C. $\S 102$ (b) (2006) (more than one year before the application date).

215. Unif. Trade Secrets Act $\$ 1$ cmt. (Unif. L. Comm'n 1985) ("Often, the nature of a product lends itself to being readily copied as soon as it is available on the market.”); see also, e.g., Roboserve, Ltd. v. Tom's Foods, Inc., 940 F.2d 1441, 1454-55 (11th Cir. 1991) (sale of plaintiff's product destroyed "any reasonable expectation of secrecy" as to unpatented parts). 
that information, systems, or methods revealed by publicly-marketed products are not true trade secrets." 216

Indeed, Pennock v. Dialogue $e^{217}$ - the very case in which the Supreme Court first announced that the Patent Act encompasses an on sale bar-involved an inventor selling an invention in a way that fails the trade secrecy standard. There, the inventor had actually sold the invention for seven years and used it in public by laying "nearly two miles and a half in length of hose" before filing his patent application. ${ }^{218}$

Nonetheless, inventions can still be considered "on sale" under Section 102, even if the information otherwise qualifies for trade secret status. ${ }^{219}$ It is entirely possible to place an invention on sale while keeping its details confidential in a way that preserves applicable trade secret protection. ${ }^{220}$ But for important public policy reasons having a lot to do with the disclosure purposes of patent law, courts still consider secret on sale activity as a bar to patentability.

In Helsinn Healthcare S.A. v. Teva Pharms. USA, Inc. ${ }^{221}$ the Supreme Court confirmed that, even post-AIA, an inventor who places his invention on sale in secret-without revealing the details of the invention-triggers the on sale bar. ${ }^{222}$ The allegedly disqualifying sale at the center of Helsinn was a "supply and purchase agreement" (a future sale agreement) that was publicly announced but kept the details of the invention secret. ${ }^{223}$ This might have qualified as a trade secret, because all parties were contractually bound to maintain the

216. Action Learning Sys., Inc. v. Crowe, No. CV-14-5112-GW(SHx), 2014 WL 12564011, at*5-6 (C.D. Cal. Aug. 11, 2014) (explaining public knowledge destroys trade secrets).

217. 27 U.S. (2 Pet.) 1 (1829).

218. Id. at 9 (explaining the invention had been in public use and publicly sold for seven years before patenting); see also supra note 54 .

219. In what was until recently the leading on-sale bar case, Pfaff $v$. Wells, the Supreme Court effectively ignored the question of publicness, announcing the rule that the on sale bar is triggered if: (1) there is a commercial "offer for sale" of the invention, and (2) the invention is in a state that is "ready for patenting." Pfaff v. Wells Elecs., Inc., 525 U.S. 55, 67 (1998); see also Helsinn Healthcare S.A. v Teva Pharms. USA, Inc., 139 S. Ct. 628, 633 (2019) (affirming Pfaff and further holding secret sales can violate the on sale bar).

220. Dennis Crouch, Did the AIA Eliminate Secret Prior Art?, PATEnTly-O (Oct. 10, 2012), https://patentlyo.com/patent/2012/10/did-the-aia-eliminate-secret-prior-art.html (discussing interpretations of how secret inventions may affect prior art in patent law). 221. 139 S. Ct. 628 (2019).

222. Id. at 630 .

223. Id. at 631 . 
secrecy of the relevant information, and the information wasn't rendered generally known or readily ascertainable in the process. ${ }^{224}$ But nonetheless the Supreme Court held it constituted "on sale" activity that triggered the on sale bar, ${ }^{225}$ thereby violating the trade secrecy standard we propose.

There are several explanations for this strict treatment of "secret sales" activity. First, inventors who sell their inventions in secret are by definition trying to commercialize them in secret. This triggers the special policy concerns addressed by the Metallizing doctrine, discussed further below. Inventors would be able to impermissibly lengthen their period of exclusivity and circumvent the choice between patenting and trade secrecy. ${ }^{226}$ Second, relatedly, the Helsinn case involved the inventor's own secret sale activity. Courts often draw a distinction between inventors' secret sales activity and third parties' secret sales activity. The latter is typically seen as less problematic and is more likely to be judged based on a trade secrecy standard: if trade secret, then not public. ${ }^{27}$ In contrast, if this same activity originates with the inventor, instead of a third party, it is more likely to be deemed a disqualifying event-in part because inventor use triggers those same policy concerns, which we will now discuss. ${ }^{228}$

224. It is hard to find a public reliance problem since under the structure of the deal the invention would only have become known to the inventor and the manufacturer. See John C. Williams, Note, Giving Meaning to "Otherwise Available to the Public": How Helsinn Perpetuates a Version of the On-Sale Bar to Patentability that Disproportionately Burdens Small Inventors, 97 TEX. L. REv. 421, 435 (2018).

225. Helsinn, 139 S. Ct. at 634.

226. See discussion infra.

227. See, e.g., W.L. Gore \& Assocs., Inc. v. Garlock, Inc., 721 F.2d 1540, 1549 (Fed. Cir. 1983) (holding sale of the output of a process by a third party not "on sale" activity because the sale was not of the invention itself, and because the invention was shared only with those who were "legally bound to keep their knowledge confidential"); see also Metallizing Eng'g Co. v. Kenyon Bearing \& Auto Parts Co., 153 F.2d 516, 519 (2d Cir. 1946) ("[I]t was not the inventor, but a third person who used the machine secretly and sold the product openly, and there was therefore no question either of abandonment or forfeiture by the inventor.”); $c f$. J.A. LaPorte, Inc. v. Norfolk Dredging Co., 787 F.2d 1577, 1583 (Fed. Cir. 1986) (holding even third-party secret "on sale" activity counts as prior art, so long as it really constitutes placing the invention on sale). 228. Woodland Tr. v. Flowertree Nursery, Inc., 148 F.3d. 1368, 1370-71 (Fed. Cir. 1998); see also MERGES \& DUFFY, supra note 25, at $589 \mathrm{n} .2$ (discussing party specific aspect of $\S 102(\mathrm{~b}))$. 


\section{b. Abandonment and the "Metallizing doctrine"}

What might seem to be the most damning body of case law for the trade secrecy standard are situations where an inventor has made commercial use of the invention in complete secret but without putting the invention itself on sale. ${ }^{229}$ Common examples include sale of output from a machine invention that can be kept in secret or use of a labor-saving process invention in the backroom. In these cases, the inventor manages to make money off the invention without disclosing it or actually putting it on sale. ${ }^{230}$

The long-standing rule in these cases is that, even though the on sale bar is not triggered, and even though the use is not "public" in the common sense of the word, secret commercialization by an inventor causes the invention to enter the prior art as a "public use" pursuant to Section 102. This is typically called the "Metallizing doctrine."

This doctrine gained fullest expression in, and takes its name from, Judge Learned Hand's decision in Metallizing Engineering Co. v. Kenyon Bearing $\mathcal{E}$ Auto Parts Co. ${ }^{231}$ In Metallizing, the patentee sought a patent for an improved process for conditioning a metal surface (called metallizing) ${ }^{232}$ More than a year before filing a patent application, the inventor had used the metallizing process commercially in secret. ${ }^{233}$ The trial court initially held that, since the "use was not public but secret," it could not be an invalidating "public use" under the statute of the time. ${ }^{234}$ But the Second Circuit overruled the trial court, holding that the commercial nature of the use by the inventor meant this was effectively a "public use" for purposes of the statutory bar of the time. ${ }^{235}$

The Metallizing doctrine actually has its origin in the earlier doctrine of "abandonment," which was added to the Patent Act in 1839 and was continued in the 1952 Act. ${ }^{236}$ It provided that a person was not entitled

229. See, e.g., Metallizing, 153 F.2d at 517-20 (explaining the differing rationale for this policy).

230. See Merges, supra note 59, at 1034.

231. 153 F.2d 516 (2d Cir. 1946).

232. Id. at 517.

233. Id. at 517-18.

234. Id. (quoting the Patent Act of 1870).

235. Judge Hand also took the time to explain why this is not an abandonment case (which presupposes a "deliberate" surrender of the right to patent), but rather a forfeiture case. See id. at 520 .

236. See 35 U.S.C. § 102(c) (1952); see also Patent Act of 1839, ch. 88, § 7, 5 Stat. 353, 354 (1839). 
to a patent if "he has abandoned the invention." 237 One way inventors "abandon" their invention was if they had been "concealing [it] and delaying application for patent in an endeavor to extend the term of the patent protection beyond the period fixed by the statute." 238 The idea was that inventors who act like they are going to rely on secrecy instead of patenting do not thereafter deserve a patent. ${ }^{239}$

There is no denying that in the abandonment and Metallizing nonpublic "public use" cases, courts hold the opposite of what the trade secrecy standard would suggest is the right outcome. Thus, we do not try to argue these cases are consistent with a trade secrecy standard of publicness. Rather, we argue that this does not dilute the trade secrecy standard's general explanatory power for deciding what is "public" under patent law. To the contrary, the exceptions only prove the general rule that trade secrecy uses of the invention don't usually count, unless a policy other than publicness is at play.

The Metallizing doctrine is clearly a policy-driven exception to what is otherwise the general rule. It is not grounded on publicness at all. ${ }^{240}$ Its purpose is to stop the inventor from unfairly extending her monopoly rents beyond what patent law was designed to provide, and to force the inventor to choose between patent and trade secret law to make sure she cannot get both. ${ }^{241}$ As Judge Hand observed in Metallizing, the inventor is supposed to make an affirmative choice between patent or trade secret protection. ${ }^{242}$ This is why the inventor who tries to commercialize in secret beyond the grace period allotted by law "forfeits his right [to patent] regardless of how little the public may have learned about the invention."243

237. 35 U.S.C. $\$ 102(c)$ (1952).

238. Elec. Storage Battery Co. v. Shimadzu, 307 U.S. 5 , 15 (1939); see also Shaw v. Cooper, 32 U.S. 292, 302 (1833) (discussing abandonment under the text of the 1793 Act, stating that "a public use does not affect the inventor's right, unless it proves that he has dedicated or abandoned his invention to the public").

239. See Macbeth-Evans Glass Co. v. Gen. Elec. Co., 246 F. 695, 698-99 (6th Cir. 1917) (supporting the holding of abandonment partly because of the "inconsistency between the right to a trade secret and the right to a patent").

240. Dmitry Karshtedt, The Riddle of Secret Public Use: A Response to Professor Lemley, 93 TEx. L. Rev. 159, 160-61 (2015); see also Alan L. Durham, Lost Art and the Public Domain, 49 ARIZ. ST. L.J. 1257, 1296 (2017).

241. See Karshtedt, supra note 240, at 164; see also Merges, supra note 59, at 1042; Lemley, supra note 79, at 1122; Ellis, supra note 112, at 259-62.

242. See Metallizing Eng'g Co. v. Kenyon Bearing \& Auto Parts Co., 153 F.2d 516, 520 (2d Cir. 1946).

243. Id. 
In other words, the most significant exception to the trade secrecy standard is motivated by the existence of trade secret law itself. The inventor did something wrong in failing to make an election between patent and trade secrecy and is being penalized for that failing in her later attempt to obtain a patent.

This principle of election is well-grounded in law and policy. ${ }^{244}$ The Supreme Court itself stressed the importance of a forced choice between patents and trade secrets in Kewanee Oil Co. v. Bicron Corp., when it explained why trade secret law was not preempted by patent law. The Court held trade secret law could co-exist with patent law, in part, because most inventors, when given the choice, would choose patent over trade secret protection. ${ }^{245}$ Crucial to the Court's reasoning was the assumption that an inventor cannot get both forms of protection; instead, the inventor has to patent within one year or rely on trade secrecy. This, in turn, allowed the Court to find that trade secret law does not conflict with the disclosure purposes of patent law and was not preempted by patent law. ${ }^{246}$

In sum, for the most part, ${ }^{247}$ the places where the trade secrecy standard is not followed can be explained by valid policy concerns separate from considerations of publicness.

\section{THE BenEFITS OF THE TRADE SECRECy STANDARD}

So far, we have shown that, at a descriptive level, courts tend to follow the trade secrecy standard for what is public enough to enter the prior art. This Part argues that the trade secrecy standard is not just

244. But see Dmitry Karshtedt, Did Learned Hand Get It Wrong?: The Questionable Patent Forfeiture Rule of Metallizing Engineering, 57 VILL. L. REV. 261, 272-77 (2012) (examining in depth the district court's finding of fact and giving a fuller picture of the factors influencing the inventor's election).

245. Kewanee Oil Co. v. Bicron Corp., 416 U.S. 470, 490-91 (1974).

246. Id. at 491-93 (recognizing the necessity of choice between trade secret and patent protection); see also Bonito Boats, Inc. v. Thunder Craft Boats, Inc., 489 U.S. 141, 166 (1989) (noting that for nearly 200 years the law of unfair competition and state trademark law have coexisted with patent law). See generally Andrew BeckermanRodau, The Choice Between Patent Protection and Trade Secret Protection: A Legal and Business Decision, 84 J. PAT. \& TRADEMARK OFf. SOC'y 371, 377, 380 (2002) (discussing the legal and commercial considerations of pursuing trade secret or patent protection).

247. Unfortunately, there is some case law suggesting that third-party trade secret uses-even those that do not rise to the level of placing the invention on sale-can potentially be deemed "public use" (or "known or used by others" under the pre-AIA law). In Part IV, we argue this a place where courts have veered from the trade secrecy standard without a good justification, and where the law should be altered accordingly. 
descriptively accurate-it is also normatively desirable. We are not alone in viewing trade secrecy as a good rule of thumb for deciding what is or is not available to the public, ${ }^{248}$ but here we work out the details for why this is so. There are several reasons courts may have turned, implicitly or explicitly, to trade secrecy principles to address the publicness of prior art.

First, as noted in Part I, the Patent Act doesn't provide an overarching definition of publicness, leaving it up to federal courts to do so. Second, trade secret law is the main legal regime with rules specifically designed to determine whether a particular disclosure of information is public or secret. ${ }^{249}$ Plentiful trade secret case law addresses the public nature of informational disclosures in a range of scenarios, from using a process inside a partially exposed factory ${ }^{250}$ to sharing information under a duty of confidentiality. ${ }^{251}$ Third, the Federal Circuit (and before that the other federal courts charged with deciding patent appeals) has been dealing with trade secret issues that arise in patent cases coming up from the district courts for over a century, so is likely to know this area of law very well. ${ }^{252}$

Yet, the availability and intuitive appeal of a tool isn't a justification for it and doesn't show it is superior to other options. In this Part, we discuss two major policy reasons for why the trade secrecy standard is advantageous for patent law and innovation policy.

\section{A. Supporting the Nonremoval Principle}

First, the trade secrecy standard for publicness prevents information from being taken away from people who have already had access to it, and who may have justifiably relied on its disclosure. As explained in Part II, the key question for prior art jurisprudence is how to decide whether a disclosure of information is sufficiently "available to the public" to trigger what Merges calls the nonremoval principle: don't

248. Ellis, supra note 112, at 267; see also Holbrook, supra note 1, at 154-56.

249. See 18 U.S.C. $\$ 1839(3)$.

250. E. I. DuPont DeNemours \& Co. v. Christopher, 431 F.2d 1012, 1013-14 (5th Cir. 1970).

251. Smith v. Dravo Corp., 203 F.2d 369, 375-76 (7th Cir. 1953).

252. 4,675 Federal Circuit (and predecessor court) cases referenced "trade secret" between 1906 and 2020 (305 reported; 4,370 unreported), according to a Lexis Advance search for "trade secret!" in all Federal Circuit, United States Court of Federal Claims, U.S. Court of International Trade, and Court of Customs and Patent Appeals cases, dated between January 1, 1906 and January 1, 2020. 
grant patents for information people already possess. ${ }^{253}$ Merges and Duffy have also called this the "anti-backsliding" principle: "[p]arties cannot obtain patent rights encompassing practices that already exist in the public domain (or that would enter the public domain prior to the expiration of the patent at issue)." 254

As this quote suggests, the nonremoval/anti-backsliding rule is supposed to be relatively strict. It has to take into account both disclosures to the relevant public that have already occurred by the critical date, and disclosures that are just about to occur, because of the context in which the invention exists or was shared in the prior art.

Trade secrecy status provides an effective way to enforce this rule. Simply put, people are more likely to have encountered and to have justifiably and legally relied upon information that does not qualify as a trade secret; and they are less likely to have encountered and justifiably and legally relied upon information that does qualify as a trade secret.

There are several specific reasons why the trade secret standard works so well in these respects.

\section{A functional approach to publicness}

First, the trade secrecy standard provides a functional standard for assessing publicness that focuses on the real-world effects of an informational disclosure, not on the form it takes. Whereas the patent prior art jurisprudence obsesses over fitting informational disclosures into categories, the trade secrecy standard recognizes that information can take essentially any form. The real issue is whether it has become sufficiently public.

\section{A well-developed concept of the relevant public}

Second, unlike patent prior art jurisprudence, trade secret law has a well-developed concept of the community from whose perspective the secrecy or publicness of a reference is determined. In trade secret law, information's publicness is determined from the perspective of "another person who can obtain economic value from the disclosure or use of the information." 255

This concept is clarifying. It illustrates that the people (or person) whose interests matter are those who might realistically want to find

253. MerGEs, supra note 25, at 142-43.

254. MERGES \& DufFY, supra note 25, at 389.

255. 18 U.S.C. $§ 1839(3)$. 
information about the invention and derive economic value from it. This can include experts in the field and employees in the relevant industry, and it can also potentially include members of the general public. ${ }^{256}$

In contrast, patent prior art cases have been inconsistent on whose perspective matters for assessing the publicness of prior art. As noted in Part III, the Federal Circuit often states the relevant public is the "person interested in the art." ${ }^{257}$ But the court has also stated that availability of a patent or printed publication to a single member of the "general public" is sufficient to turn a reference into prior art. ${ }^{258}$

Some have suggested the patent prior art standard is fundamentally much stricter than trade secret law's, and that it is "much easier to lose patent rights than trade secrets." ${ }^{259}$ But we don't think that is the case. Trade secret law's "readily ascertainable" prong supplements the "not generally known" prong, and renders information public, so long as it can be discerned with "reasonable effort" utilizing legal means. ${ }^{260}$ Second, the "reasonable measures" requirement supplements the trade secrecy standard even further, rendering information public if it's not protected using reasonable secrecy precautions. ${ }^{261}$

The Federal Circuit has already acknowledged the similarity between the two legal regimes' concepts of publicness, albeit going in the opposite direction-citing to patent prior art jurisprudence to explain why a trade secret disclosed in a foreign patent is too public to

256. Holbrook similarly asserts that it makes more sense to ask whether prior art would be accessible to a "reasonable competitor," than to a PHOSITA, and that " $[\mathrm{t}] \mathrm{o}$ inform the reasonable competitor construct, patent law may want to turn to trade secrecy." Holbrook, supra note 1 , at 193.

257. See In re Hall, 781 F.2d 897, 898-99 (Fed. Cir. 1986) (noting the "'printed publication' bar requires that the publication be accessible to the interested public").

258. Mark Lemley et al., 1 Intellectual Property in the New Technology Age: 2020181 (2020); see also Voter Verified, Inc. v. Premier Election Sols., Inc., 698 F.3d 1374, 1380 (Fed. Cir. 2012) (website public); In re Klopfenstein, 380 F.3d 1345, 1352 (Fed. Cir. 2004) (presentation public).

259. LemLey ET AL., supra note 258, at 181. But as discussed in Part III, we think trade secret law is not less strict because of the need to apply the "readily ascertainable" and "reasonable measures" requirements in addition to the "generally known" requirement. See discussion in Part III, supra.

260. 18 U.S.C. $§ 1839(3)$; see, e.g., Flotec, Inc. v. S. Rsch., Inc., 16 F. Supp. 2d 992, 1000 (S.D. Ind. 1998).

261. 18 U.S.C. $§ 1839(3)$. 
be a trade secret. ${ }^{262}$ Patent prior art jurisprudence, in turn, could benefit from drawing more expressly on trade secret law. ${ }^{263}$

\section{Highlighting the importance of measures to maintain secrecy}

The most important reason for patent prior art jurisprudence to embrace trade secret law's standard for publicness is that trade secrecy specifically addresses whether information has been deliberately kept secret. This creates a critical additional layer of protection against removal of information from the public.

When it comes to protecting others' reliance on known information, the "reasonable measures" requirement serves two functions.

First, when a possessor of information about a new invention (including but not limited to the inventor) takes measures to keep the information secret, this supports an inference of actual secrecy. ${ }^{264}$

Second, when an inventor or other actor in possession of an invention takes measures to preserve its secrecy, like confidentiality ledgers and NDAs, this places other people on "notice" that the invention is intended to be kept confidential and that recipients of the information concerning the invention are not free to use it in their own endeavors. ${ }^{265}$ If others use the information anyway, ignoring these signs, this would constitute a "bad act" that would subject them to a trade secret lawsuit or a patent infringement claim if the invention was timely patented. ${ }^{266}$ By the same token, where trade secrecy is established it seems fair to allow the inventor to get a patent on the invention, even if it would later deprive those "on-notice" recipients of the right to make, use, or sell the invention in future.

On the other hand, if the opposite is true-if there were too few secrecy precautions in place-it does not seem fair to deprive people of the ability to freely use what they've gleaned without obvious restrictions on reuse. The Federal Circuit's holding in Baxter International, Inc. $v$.

262. See Ultimax Cement Mfg. Corp. v. CTS Cement Mfg. Corp., 587 F.3d 1339, 1355-56 (Fed. Cir. 2009).

263. Accord Holbrook, supra note 1, at 193; Anderson, supra note 113, at 921.

264. Metallurgical Indus. Inc. v. Fourtek, Inc., 790 F.2d 1195, 1199 (5th Cir. 1986).

265. Robert G. Bone, Trade Secrecy, Innovation, and the Requirement of Reasonable Secrecy Precautions, in The Law ANd Theory of Trade SEcrecy: A Handbook of Contemporary RESEARCH, supra note 102, at 46-47, 59.

266. If the bad actor goes on to disclose the invention further, such as through public sale, the inventor would not be able to obtain patent protection and would only have a trade secret remedy, see Evans Cooling Sys., Inc. v. Gen. Motors Corp., 125 F.3d 1448, 1454 (Fed. Cir. 1997), discussed infra. 
Cobe Laboratories, Inc. ${ }^{267}$ provides a highly illuminating illustration of this second scenario and shows how courts use the reasonable secrecy precautions inquiry to protect these reliance interests. ${ }^{268}$

In Baxter, the Federal Circuit found that a non-patentee third-party research scientist named Dr. Jacques Suaudeau had made "public use" of a claimed centrifuge invention, even though Dr. Suaudeau was essentially doing "private laboratory work." 269 The patent was for a sealless centrifuge for separating blood into its components. ${ }^{270} \mathrm{Dr}$. Suaudeau had used the centrifuge in a National Institute of Health (NIH) laboratory to conduct tests for around forty-three hours. ${ }^{271}$

Note that there is no "forfeiture" or "abandonment" principle at play here: Dr. Suaudeau was not himself the patentee. Instead, this was a case about protecting the public's interests in the information. Yet there was really only one identifiable reason for the court's conclusion of publicness: Dr. Suaudeau had not undertaken any significant efforts to conceal his use from visitors to the lab. ${ }^{272}$ In fact, Dr. Suaudeau testified that the NIH had an "anti-secrecy" policy, meaning duties of confidentiality were deliberately not put in place. ${ }^{273}$ As the court described it, the laboratory "was located in a public building," with "people coming and looking, people flowing into the lab" and "others at NIH [coming] into [the doctor's] laboratory and observ[ing] the centrifuge in operation, including co-workers, who were under no duty to maintain it as confidential." 274

The court seemed concerned with the prospect of taking away from the public an invention to which they already had relatively unrestricted access. Any of the other people could have discerned Dr. Suaudeau's centrifuge, assessed its operation, or even taken photos or notes on how it worked. Those people would have had no reason to think they could not thereafter use or copy the invention and would have been justified in doing so. If the patentee (Baxter) were able to

267. 88 F.3d 1054 (Fed. Cir. 1996).

268. Id. at 1058-59. For an engaging summary, discussion, and critique of this case, see Edwin D. Garlepp, Baxter v. Cobe: Public Use or Secret Prior Art?, 4 J. Intell. Prop. L. 381, 397-98 (1997).

269. Baxter, 88 F.3d at 1060-62. This decision irritated Judge Newman. Id. at 106163 (Newman, J., dissenting.).

270. Id. at 1056 .

271. Id.

272. See id. at 1058 .

273. Id. at 1059 .

274. Id. at 1058-59 (quoting Dr. Suaudeau's testimony). 
patent the centrifuge, this would unfairly deprive those people of what they already had, and potentially subject them to a patent infringement lawsuit for doing what they had no reason to believe was off limits.

By assessing whether "reasonable efforts" were used to safeguard the centrifuge invention, the Baxter court was able to discern whether people interested in the art might have plausibly come into contact with and reasonably relied upon it. (Note too that the way the Baxter court assessed the "reasonableness" of the lab's secrecy precautions is precisely analogous to how courts do so in trade secret cases involving the scenario of a facility that is open to visitors. ${ }^{275}$ )

An even more extreme example of the protective function of secrecy precautions in the prior art analysis is JumpSport, Inc. v. Jumpking, Inc. ${ }^{276}$ In JumpSport, the Federal Circuit held that a patent on an improved trampoline with a safety fence extending above the rebounding surface was barred due to prior "public use" of the trampoline by the inventor's neighbors in the inventor's own backyard. ${ }^{277}$ Like the undergarment in Egbert, the trampoline in JumpSport forces us to stretch our imagination of what is "public."278

Yet when seen from the trade secrecy lens, the inventor's decision to use the trampoline in his backyard and give his neighbors access, was a "public" use. The inventor didn't "control access to [the trampoline] or make any effort to keep it confidential." ${ }^{\prime 279}$ The fact that the inventor failed to exercise control or to use confidentiality procedures wasn't a moral failing or anything like that. It just suggests that information about the trampoline probably leaked out to others, and that anyone who saw it would have been justified in relying on it and making a copy

275. Compare Columbus Bookkeeping \& Bus. Servs., Inc. v. Ohio State Bookkeeping, LLC, No. 11AP-227, 2011 Ohio App. LEXIS 5655, at*16 (Ohio Ct. App. Dec. 30, 2011) (holding the client list was not a trade secret because it was maintained in a shared office, computer passwords were easily accessible, and filing cabinets were often left unlocked), with Anaconda Co. v. Metric Tool \& Die Co., 485 F. Supp. 410, 415 (E.D. $\mathrm{Pa}$. 1980) (holding the hose production process was a trade secret because visitors of the plant were placed under security observation, escorted throughout, and screens and barriers were placed around the proprietary machines).

276. 191 F. App'x 926 (Fed. Cir. 2006).

277. Id. at 929,935 .

278. See Holbrook, supra note 1, at 156 (discussing how this line of cases is also inconsistent with the possession requirement).

279. JumpSport, 191 F. App'x at 935. 
of it. In those circumstances, it would be unfair to take back what had lawfully been obtained and justifiably relied upon.

\section{B. $\quad$ Streamlining Inventors' Incentives}

The second major benefit of the trade secrecy standard is that it protects inventors' (and patentees ${ }^{280}$ ) interests by providing them with a clear and efficient guidepost for how to keep their information out of the prior art. It keeps inventors focused only on taking "reasonable," i.e., efficient, secrecy precautions, and helps them to recognize when they've engaged in a triggering prior art event. ${ }^{281}$

The patent system serves an important function in affecting inventors' incentives to invent and commercialize their inventions, ${ }^{282}$ and to disclose new information to the public through the patent system. ${ }^{283}$ Therefore, a major concern with our proposal to use trade secrecy as the standard for patent prior art is that too much will be considered "public," and that inventors will too frequently be denied patents. Think of Baxter and JumpSport, where inventors lost the right to patent due to relatively private disclosures-in a lab and a backyard respectively. Think of poor Mr. Barnes in Egbert, who shared his invention only in the privacy of his home. These forfeitures have troubled some commentators. ${ }^{284}$ Timothy Holbrook, for instance, suggests that "Egbert and its progeny" (sometimes called "noninforming" use $\operatorname{cases}^{285}$ ) are "wrongly decided" because they "do not demonstrate sufficient communication of the invention to the public." 286

However, while it sometimes appears harsh, we think the trade secrecy standard actually strengthens inventors' incentives by making the path to patenting more efficient and clarifying the scenarios that will

280. We discuss patentees and inventors as the same group, but of course patents are freely assignable, and inventors do not always own or retain the patent on their inventions. 35 U.S.C. $\$ 261$.

281. See, e.g., Rockwell Graphic Sys., Inc. v. DEV Indus., Inc. 925 F.2d 174, 177-78 (7th Cir. 1991) (applying the reasonable efforts test to patent piece drawings).

282. See Camilla A. Hrdy, Commercialization Awards, 2015 WIS. L. REv. 13, 24-36

(2015) (discussing at length the interplay of the patents and commercialization).

283. Jeanne C. Fromer, Patent Disclosure, 94 Iowa L. Rev. 539, 553-54 (2009).

284. Holbrook, supra note 1, at 154-56.

285. AdELMAN, supra note 155, at 121.

286. Holbrook, supra note 1 , at 156. Holbrook argues instead for a "possession" framework, asking: was the information within the public's possession or not? Id. at 194; see also AdELMAN, supra note 155, at 118-25. 
trigger a prior art event. To see the positive effect on incentives, we must assess two different scenarios: inventor prior art and third-party prior art.

\section{Inventor prior art}

The first scenario is where the prior art is created by the inventor herself. ${ }^{287}$ Start with the corset-spring disclosed and used by the inventor's partner in Egbert more than a year prior to filing for a patent. Imagine this inventor-generated use is treated as prior art by virtue of the fact that trade secrecy failed since Mr. Barnes didn't take sufficient secrecy precautions.

It is unlikely this would undermine inventors' incentives to invent, commercialize, and disclose. Far from it. When the barring public use was done by the inventor or someone in the inventor's control, inventors can patent these inventions-they just have to take "reasonable" measures to keep the invention secret until they are ready and file for a patent within one year of failing to do so. ${ }^{288}$

What is more, "reasonableness" in trade secret law is similar to the "reasonableness" standard of tort law: it only requires inventors to take actions to the extent the costs of doing so are outweighed by the benefits. So, for example, if the expected value of an invention is $\$ 100$, and the risk others will copy it is very low, she should not be expected to spend millions on secrecy precautions. ${ }^{289}$ As Judge Posner famously put it, "perfect security is not optimum security."290

So in Egbert, Barnes was perfectly free to patent his corset, so long as he took "reasonable" measures to keep the corset springs secret in context. This would not mean Barnes had to spend thousands of dollars on fences and locks or decline to share and test at all. He could, for example, have asked his partner and house guest to sign nondisclosure agreements, and thereby put them on notice that they should not share the corset with others. ${ }^{291}$

Moreover, imagine Barnes failed to take the necessary precautions, slipped up, and allowed his invention to lose trade secrecy status. Not only would this deprive him of the right to patent, assuming the use

287. Cf. Amy R. Motomura, Innovation and Own Prior Art, HASTINGS L.J. (forthcoming 2021).

288. Cf. 18 U.S.C. $§ 1839(3)$.

289. William M. Landes \& Richard A. Posner, The Economic Structure of INTELLECTUAL PROPERTY LAW 357 (2003).

290. Rockwell Graphic Sys. v. DEV Indus., Inc. 925 F.2d 174, 180 (7th Cir. 1991).

291. See supra notes 99-101 and accompanying text. 
was discovered by an examiner or challenger in court, but he would also lose the right to protect his invention as a trade secret. As a result, Barnes would have one clear choice: he would have to file a patent within one year, or (under the AIA) make a "saving disclosure" and file within one year of that event. ${ }^{292}$ In sum, under the trade secrecy standard, inventors like Barnes would have a certain rule telling them what to do-take efficient secrecy precautions in the early stages of inventing. And they would know the consequences of failing to do sono patent, and no trade secret. These rules would inform inventors' actions, reducing uncertainty and guiding them towards efficient secrecy precautions.

A prescriptive message emerges from this discussion. There is currently a good deal of uncertainty among inventors, especially researchers without the benefit of good legal advice, over what will count as prior art and bar them from patenting. ${ }^{293}$ If trade secrecy were the rule for publicness, inventors would know more precisely what they need to do in order to preserve their rights to patent: keep your invention as a trade secret (but don't commercialize it ${ }^{294}$ ), and if you fail to do so, take remedial actions like patenting as soon as possible, and at the greatest within one year.

What would this mean? Formalities such as express confidentiality agreements are important in trade secret law, giving courts an easy-toapply standard for what constitutes sufficient precautions. ${ }^{295}$ But they don't rule the day. And nor should they in the patent prior art context. For sure, an express confidentiality agreement is preferred to shield against a finding of "public use." ${ }^{296}$ But, like in Moleculon, discussed above, there doesn't necessarily need to be an express NDA guarding

292. 35 U.S.C. § 102(b); see also supra Part I.

293. See, e.g., Jason Ratanen \& Madison M. Colon, Can Public Universities Patent Their Research?: The Tension Between Open Records Laws and Patentability, (forthcoming 2021) (on file with authors).

294. This would trigger the Metallizing exception. Metallizing Eng'g Co. v. Kenyon Bearing \& Auto Parts Co., 153 F.2d 516, 519 (2d Cir. 1946). As explained in note 227, supra, we do not mean "trade secret" in the sense of deriving economic value.

295. David S. Almeling et al., A Statistical Analysis of Trade Secret Litigation in State Courts, 46 Gonz. L. Rev. 57, 80-83 (2011).

296. See, e.g., Diodem, LLC v. Lumenis Inc., No. CV03-2142 GAF (RCx), 2005 WL 6220720 , at *12-13 (C.D. Cal. Sept. 16, 2005) (patentee defeats allegation of public use by demonstrating that any use of the invention by experimenters at company required them "to sign strict confidentiality and non-disclosure agreements to maintain the trade secret status of the inventions"). 
the disclosure. In fact, in Moleculon itself, the Federal Circuit expressly stated that "the presence or absence of such an agreement is not determinative of the public use issue. ${ }^{297}$ From the trade secrecy lens, this was all the more true given that Nichols was relatively unsophisticated, and was dealing only with close friends and colleagues, or a trusted company insider. ${ }^{298}$ In those environs, courts should allow trade secret holders much more latitude in utilizing nondisclosure agreements. ${ }^{299}$

The point is that, far from dampening patenting inventors' incentives to invent and patent, the trade secrecy standard streamlines them, encouraging inventors to take efficient levels of precaution as they prepare to file for patents. Inventors don't have to embark on maximum security-just "reasonable" security. ${ }^{300}$ In addition, inventors get the advantage of a clear rule about when their inventions are going to be deemed public and in the prior art. This helps them choose the right decision to help them protect their inventions.

\section{Third-party prior art}

The more difficult scenario is where the prior art is generated by a third-party over which the inventor has no control. Under a trade secret standard, third parties' non-trade secret disclosures, including even a "private" laboratory use like that in Baxter or a tricky-to-locate thesis like that in In re Hall, can enter the prior art and ruin a later inventor's chance to patent.

The rule is indeed harsher here. To state the obvious, inventors cannot save themselves from third-party disclosures by taking "reasonable measures" to protect their inventions. And they can't necessarily patent within one year of these disclosures since they may not know about them. To give one extreme example, in Evans Cooling Systems, Inc. v. General Motors Corp. ${ }^{301}$ the Federal Circuit held that the invention (relating to a car motor) entered the prior art due to a third party's (General

297. Moleculon Rsch. Corp. v. CBS, Inc., 793 F.2d 1261, 1266 (Fed. Cir. 1986) ("[T] he presence or absence of such an agreement is not determinative of the public use issue. It is one factor to be considered in assessing all the evidence." (citations omitted)).

298. Id. at 1265-66.

299. See, e.g., Learning Curve Toys, Inc. v. PlayWood Toys, Inc., 342 F.3d 714, 72526 (7th Cir. 2003) (holding plaintiffs undertook reasonable efforts to maintain secrecy of toy prototype despite failing to secure a written confidentiality agreement).

300. See Rockwell Graphic Sys., Inc. v. Dev Indus., Inc., 925 F.2d 174, 180 (7th Cir. 1991).

301. 125 F.3d 1448, 1454 (Fed. Cir. 1997). 
Motors) sale of cars containing the invention more than a year before the inventor filed his patent-even though General Motors itself had misappropriated the inventor's trade secret. ${ }^{302}$ The inventor's (John Evans) careful use of his invention as a trade secret did not protect his ability to patent at a later date because the third party took it and sold it, quite publicly, in violation of the on sale bar. The court held that Evans could not patent his pilfered invention. ${ }^{303}$ GM's usage created prior art under Section 102, leaving the inventor without a patent.

So perhaps inventors like Mr. Evans will make fewer investments in inventing and patenting, when confronted with the uncontrollable risk that third-party prior art will bar them. However, this does not seem likely. As an initial matter, despite the harsh consequence for inventors like Evans, it seems clear that the nonremoval principle should triumph in this case. GM had placed the invention into the public domain by selling it on the open market in GM cars, free for others to use and reverse engineer. ${ }^{304}$ It would be unfair to take this information back.

Moreover, concerns about inventor incentives in these third-party prior art cases are somewhat illusory. One cannot realistically be concerned that people would not bother to derive inventions in light of the risk of barring third-party party disclosures. Just look at what usually happens in these third-prior art cases-someone else didinvent them. ${ }^{305}$ Baxter and In re Hall are perfect examples of where the patent system does not need to reward a later inventor for re-inventing something that already exists in the prior art. ${ }^{306}$ In those cases, it would be better to encourage inventors to find these preexisting inventions

302. Id. at 1452; see also id. at 1450 (noting that "GM and its independent dealers had placed the patented invention on sale prior to the critical date with the introduction of its 1992 Corvette").

303. Id. at 1454 .

304. See Action Learning Sys., Inc. v. Crowe, No. CV-14-5112-GW(SHx), 2014 WL 12564011, at*6 (C.D. Cal. Aug. 11, 2014) ("Matters which are completely disclosed by the goods which one markets cannot be his secret." (quotations omitted)).

305. Mark A. Lemley, The Myth of the Sole Inventor, 110 MiCH. L. Rev. 709, 736-37 (2012).

306. The commercialization incentive problem is somewhat more plausible. The mere existence of the enabling doctoral thesis in In re Hall, for instance, does not indicate the invention had been brought to market. In re Hall, 781 F.2d 897, 899-900 (Fed. Cir. 1986). However, the grant of a patent hardly guarantees commercial success. See Ted Sichelman, Commercializing Patents, 62 STAN. L. Rev. 341, 343-44 (2010) (arguing patent law does not create sufficient incentives to actually commercialize). So it seems foolhardy to change the rule on this basis alone, giving patents for inventions that might already be known to people in the field on the hope that this will launch them to market. 
by searching the prior art. Why risk violating the nonremoval principle simply for the sake of "reinventing the wheel"? 307

For sure, a case like Evans is trickier, because the third party derived the prior art from the inventor. But even in these derivation cases, the first inventors still have other remedies. First, if derivation rises to the level of misappropriation of the inventor's trade secret, the inventor would have a trade secret claim against the third party. ${ }^{308}$ Second, if the third party goes on to try to get its own patent, the inventor could argue the invention was improperly derived from another and thus not suitable for a patent under various provisions of the Patent Act. ${ }^{309}$

Patent law's disclosure policy raises additional concerns, at least in some prior art cases. Obviously, if the barring third-party prior art is a U.S. patent or a traditional scientific publication, there is no additional incentive to disclose required, assuming the information is sufficiently enabling. ${ }^{310}$ But as we've seen, there are harder cases like Baxter (use within a lab) and Shimadzu (use within a firm), where even if the disclosure is technically enabling, because a hypothetical PHOSITA watching the use could discern how to make and use the invention, it does not disclose the information to a meaningful number of people in a widely accessible forum. If others can't thereafter get a patent for

307. On the economics of prior art searching, see MERGES \& DuFFy, supra note 25, at 427-30; see also LANDES \& POSNER, supra note 289, at 303.

308. See Evans Cooling Sys., Inc., 125 F.3d at 1454 ("Evans is not without recourse if GM in fact misappropriated his invention. Evans would have an appropriate remedy in state court for misappropriation of a trade secret.").

309. Pre-AIA, the Patent Act included a specific prohibition on patenting something the purported inventor did not actually invent. 35 U.S.C. § 102(f) (2006). Post-AIA, there are various options, including a derivation proceeding. 35 U.S.C. $§ 135$ (2018); see also Dennis Crouch, With 102(f) Eliminated, Is Inventorship Now Codified in 35 U.S.C. 101? Maybe, but Not Restrictions on Patenting Obvious Variants of Derived Information, PAtently-O (Oct. 4 2012), https://patentlyo.com/patent/2012/10/with-102feliminated-is-inventorship-now-codified-in-35-usc-101.html.

310. For "patented" and traditional printed publication prior art, the disclosure probably would be enabling. After all, "[t]he $\$ 112$ requirement that patented inventions be reproducible by a PHOSITA without undue experimentation [is] similar to the standards of scientific publication." Lisa Larrimore Ouellette, Do Patents Disclose Useful Information?, 25 HaRv. J.L. \& TeCH. 545, 553-54 (2012); see also Sean B. Seymore, The Teaching Function of Patents, 85 Notre Dame L. Rev. 621, 628 (2010) (noting how science publications can have superior disclosures to patents). But see Seymore, supra note 1, at 925, 932-33 (noting that to meet the "anticipatory enablement" standard, a prior art reference need not actually fully teach the invention and that in some fields effectively "nonenabling" prior art can bar future patents). 
the invention, this could limit incentives for anyone to ever disclose the invention to a critical mass of people.

On the other hand, even in cases like Baxter, vigilant, forwardthinking inventors can still patent these inventions, notwithstanding the risk of preempting third-party prior art. They just have to do so quickly, before the third-party prior art comes out. In this sense, the harsh aspect of the trade secrecy standard simply heightens one of Section 102's key functions: to encourage "prompt filing" of patents and "prompt and widespread disclosure of inventions [to the public]." 311 It also aligns with the AIA's goals in transitioning to a firstto-file regime. Recall that under the AIA's first-to-file rule, inventors must strive to patent as quickly as possible in order to achieve priority ${ }^{312}$ So treating third-party non-trade secret disclosures as prior art supports this goal, because it enhances the need to file promptly.

In sum, the trade secrecy standard performs an essential role in protecting the public's access to inventions that have become available to the public, and simultaneously supports and streamlines inventor's incentives.

\section{The third-party problem}

As we alluded to in Part III, there is one significant set of cases where the courts may be getting it wrong: cases where a third party (not the inventor) is employing the invention as a trade secret, but where the courts nonetheless hold this enters the prior art. This situation is usually going to arise only for a process invention or something that is possible to keep secret while benefitting from it commercially, like software or a machine for making consumer products. Courts sometimes classify this as prior art, even though it is done in secret. ${ }^{313}$

An extreme example is Lockwood $v$. American Airlines, Inc. ${ }^{314}$ American Airlines was using its internally developed "SABRE" reservation system in secret for many years prior to the patentee (Lockwood's) filing date. ${ }^{315}$ The Federal Circuit held American Airlines' use constituted a

311. See, e.g., Netscape Commc'ns Corp. v. Konrad, 295 F.3d 1315, 1320 (Fed. Cir. 2002) (applying 35 U.S.C. § 102(b)); Baxter Int'l, Inc. v. Cobe Lab’ys, Inc., 88 F.3d 1054, 1058 (Fed. Cir. 1996) (describing a policy of Section 102(b) as including "favoring the prompt and widespread disclosure of inventions"); see also supra Part I.

312. Alternatively, they can perform a saving disclosure within one year before filing. Merges, supra note 59, at 1025, 1038; see also 35 U.S.C. § 102(b).

313. See supra Section III.C.

314. 107 F.3d 1565, 1568 (Fed. Cir. 1997).

315. Id. at 1570 . 
"public use" of the reservation system and rendered the invention "known or used by others" within the meaning of Section 102-even though the system was not placed on sale and the airline was apparently deliberately keeping the system as a trade secret. ${ }^{316}$

This case contradicts a lot of the case law we discussed in Part III, like Rosaire and Shimadzu, where prior use or knowledge was prior art only because users failed to keep the invention sufficiently secret. Why should an airline's trade secret usage enter the prior art against another's later attempt to patent? There is no public reliance problem. There is no Metallizing inventor commercialization problem. It is also not even possible to say, as it is for third-party secret "on sale" activity, that "Congress said so." 317

There is one obvious justification for holding that American Airlines' prior trade secret usage of the reservation system in Lockwood was prior art. This was simply the fact that American Airlines was getting sued for using a process that it itself had invented, and that it was using long before the inventor got a patent on it. ${ }^{318}$ It wouldn't have seemed fair to let the company get sued for what they'd already been using for such a lengthy period. What's more, it appears there were many other airlines using the reservation system besides American Airlines-and they might have been about to get sued too. ${ }^{319}$ Put differently, there actually was a serious reliance problem, even though the invention hadn't entered the public domain, because it was still a trade secret. Thus, the court had to invalidate the patent.

The concerns motivating Lockwood have to some degree been solved by the amendments in the AIA. In the AIA, we moved to a first-to-file system, so the fact that American Airlines invented first should not matter as much as it might have under the old first-to-invent system. ${ }^{320}$

316. American Airline's own expert conceded "that the essential algorithms of the SABRE software were proprietary and confidential." Id.

317. Cf. Helsinn Healthcare S.A. v. Teva Pharms. USA, Inc., 139 S. Ct. 628, 634

(2019) (holding inventor's secret on sale activity prior art given that "Congress did not alter the meaning of 'on sale' when it enacted the AIA").

318. Another possible justification is that the public was already getting the benefit of the invention. But this is an outlier view for how to judge public availability. $C f$. Burk \& Lemley, supra note 155 , at $379-80$.

319. Lockwood, 107 F.3d at 1570.

320. See Abrams \& Wagner, supra note 49, at 520 (discussing the shift away from first-to-invent rule). 
Relatedly, Congress has added a limited "prior user defense" precisely to protect the interests of prior inventors like American Airlines. ${ }^{321}$

Although the prior user defense could (and arguably should) be much stronger than it is, the defense makes clear that at least some trade secret uses by third parties other than the inventor will not be deemed infringing. ${ }^{322}$ This in turn indicates that those uses are not in the prior art, for there would be no purpose for a prior user defense if a third party's prior use counted as invalidating prior art against the patent being enforced. ${ }^{323}$ Especially now that we have a prior user defense, trade secret uses by third parties, other than the inventor, should not count as prior art. ${ }^{324}$

\section{Fleshing Out "Otherwise Available to the Public"}

A final benefit of the trade secrecy standard is to clarify what the phrase "available to the public" means in the AIA. As explained in Part I, in 2011 Congress added a new phrase to Section 102, indicating that prior art now includes anything that renders the claimed invention "otherwise available to the public." 325 This textual addition has led to considerable uncertainty and debate. ${ }^{326}$ Some commentators initially

321. Section 273 of the Patent Act provides a limited defense from patent infringement for prior users. However, section 273 only applies for process patents (or a patent for a machine used in a process), and the defendant must have "acting in good faith, commercially used the subject matter in the United States" either one year before the patent filing date or one year before a saving disclosure under $\$ 102$ (b). 35 U.S.C. $§ 273$; see also, e.g., Edward D. Manzo, The Impact of the America Invents Act on Trade Secrets, 13 J. Marshall Rev. Intell. Prop. L. 497, 502 n.18, 518 (2014).

322. Anthony A. Hartmann, The New Prior-User-Rights Defense: What Trade Secret Holders Need to Consider, NAT'L L.J. (2012) (noting that “while the scope of prior-userright defense has certainly been expanded" under the AIA, there remain "many uncertainties and risks" associated with raising the defense).

323. For similar arguments, see, for example, Joe Matal, A Guide to the Legislative History of the America Invents Act: Part I of II, 21 FED. CIR. BAR J. 435, 451-64 (2012); Jeffrey P. Duke, The First Inventors Defense Act (35 U.S.C. § 273): Have Prior User Rights in Patent Law Been Resurrected?, 20 ST. Louis U. Pub. L. Rev. 223, 242 (2001).

324. We are less concerned about third-party trade secret sales of the invention. These usually will fail the trade secrecy standard anyway. And also Congress has used the word "on sale" in the statute. Helsinn Healthcare S.A. v. Teva Pharms. USA, Inc., 139 S. Ct. 628, 634 (2019); see supra Part III.

325. 35 U.S.C. $\$ 102(\mathrm{a})(1)$; see supra Part I.

326. See, e.g., Williams, supra note 224, at 422-23; Raja Chatterjee, The Patent On-Sale Bar Post-Helsinn and Its Effect on the Pharmaceutical Industry, 18 CHI. Kent J. INTELL. Prop. 207, 226-27 (2019); see also Caroline A. Schneider, The New Novelty: Defining the Content 
argued that, post-AIA, references are only invalidating if they meet a heightened standard of publicness. ${ }^{327}$ Even the U.S. Patent Office (USPTO) initially adopted this view. ${ }^{328}$ Others disagreed, arguing that the addition of the phrase "otherwise available to the public" merely creates a new "catchall" category of prior art without necessarily mandating that other categories be more public than before ${ }^{329}$

The trade secrecy standard informs the question of what "available to the public" means in two ways. First, courts should take a signal from this new catchall and shift to a functional analysis. Rather than focusing on fitting activity into statutory categories, they should assess the underlying question of publicness. Trade secrecy status should be the starting point for a Section 102 analysis. Second, to the extent the addition of "otherwise available to the public" indicates there can be new forms of prior art not contained in the old categories, trade secrecy provides a simple answer to what type of activity might qualify. Simply put, it encompasses trade secrecy-destroying disclosures that don't fall into one of the other categories. We give two examples.

A first example is an unwritten oral disclosure of information about an invention (say, on a telephone call or a Zoom meeting) that reaches a significant number of people in the field-thereby rendering the information generally known-or that is not given under circumstances demonstrating reasonable efforts were taken to maintain secrecy. This would not technically count as a printed publication or a public use of the invention under patent prior art jurisprudence, but it would render information no longer a trade secret and, therefore, legally available to the public.

A second example of a new form of non-trade secret, "available to the public," prior art is where numerous companies use a process invention in secret such that it becomes general knowledge in the industry. In this case, there may not even be a singular disclosure that can be identified, but the invention becomes known to enough people in the industry that it no longer would qualify as any one company's

of "Otherwise Available to the Public", 41 J. LEGIS. 151, 161-62 (2014) (assessing whether "otherwise available to the public" should be informed by European law).

327. See Williams, supra note 224, at 424; see also Brief for Congressman Lamar Smith as Amicus Curiae Supporting Petitioner, Helsinn Healthcare S.A. v. Teva Pharms. USA, Inc., 139 S. Ct. 628 (2019) (No. 17-1229).

328. U.S. Patent Office Manual of Patent Examining Procedure § 2152.02(d) (2014).

329. Lemley, supra note 79, at 1127. 
trade secret because it has become generally known. ${ }^{330}$ This information might be deemed to enter the prior art under an interpretation of "otherwise available to the public" that is informed by the trade secrecy standard. Once information about an invention becomes "generally known" to people in the relevant industry, or even simply "readily ascertainable" to them using "proper means," it would be deemed to have entered the prior art. The information could not be taken back through operation of a patent.

\section{CONCLUSION}

Without saying so, the courts are applying trade secrecy rules in patent prior art cases. It is a simple, if currently unstated, rule: if a disclosure of information does not qualify as a trade secret, then it will be deemed to have entered the prior art; if a disclosure does qualify as a trade secret, then it will not be deemed to have entered the prior art.

We think the trade secrecy standard for prior art should be recognized more explicitly than it currently is. The trade secrecy standard for patent prior art helps courts and other decisionmakers efficiently and fairly draw the proper line between secret and public information. It helps enforce the nonremoval principle by protecting members of the relevant public from being deprived of what they have already justifiably and lawfully relied upon. And it streamlines inventors' incentives because it makes the path to patenting more efficient and clarifies the steps inventors must take to prevent their inventions from falling into the prior art.

330. 18 U.S.C. $§ 1839(3)$; cf. Hutchison v. KFC Corp., 51 F.3d 280, 280 (9th Cir. 1995) (holding in a trade secret case that a fried chicken recipe was not a trade secret because it was "generally known in the industry"). 


\title{
Mitchell Hamline Open Access
}

Mitchell Hamline Open Access is the digital archive of Mitchell Hamline School of Law. Its mission is to preserve and provide access to our scholarly activities, for the benefit of researchers and members of the legal community.

Mitchell Hamline Open Access is a service of the Warren E. Burger Library.

open.mitchellhamline.edu

\author{
$\mathrm{MH}$ \\ MITCHELL | HAMLINE \\ School of Law \\ (C) Mitchell Hamline School of Law \\ 875 Summit Avenue, Saint Paul, MN 55105 \\ mitchellhamline.edu
}

